\title{
Russia: Grasping the Reality of Nuclear Terror
}

\section{Citation}

Saradzhyan, S. 2006. "Russia: Grasping the Reality of Nuclear Terror." The ANNALS of the American Academy of Political and Social Science 607 (1) (September 1): 64-77. doi:10.1177/0002716206290964.

\section{Published Version}

doi:10.1177/0002716206290964

\section{Permanent link}

http://nrs.harvard.edu/urn-3:HUL.InstRepos:27029092

\section{Terms of Use}

This article was downloaded from Harvard University's DASH repository, and is made available under the terms and conditions applicable to Other Posted Material, as set forth at http:// nrs.harvard.edu/urn-3:HUL.InstRepos:dash.current.terms-of-use\#LAA

\section{Share Your Story}

The Harvard community has made this article openly available.

Please share how this access benefits you. Submit a story.

Accessibility 


\title{
Russia: Grasping Reality of Nuclear Terror
}

\author{
Simon Saradzhyan
}

2003-02

March 2003 


\title{
CITATION AND REPRODUCTION
}

This document appears as Discussion Paper 2003-02 of the Belfer Center for Science and International Affairs. BCSIA Discussion Papers are works in progress. Comments are welcome and may be directed to the author in care of the Center. Electronic copies of this report are available through the Center's website, listed below.

This paper may be cited as: Simon Saradzhyan. "Russia: Grasping Reality of Nuclear Terror." BCSIA Discussion Paper 2003-02, Kennedy School of Government, Harvard University, March 2003.

The views expressed in this paper are those of the author and publication does not imply their endorsement by BCSIA and Harvard University. This paper may be reproduced for personal and classroom use. Any other reproduction is not permitted without written permission of the Belfer Center for Science and International Affairs. To obtain more information, please contact:

\author{
Michelle Von Euw \\ Editor, ISP Discussion Paper Series \\ International Security Program \\ Kennedy School of Government \\ 79 John F. Kennedy Street \\ Cambridge, MA 02138 \\ telephone (617) 495-1914; facsimile (617) 496-4403 \\ email is@harvard.edu. \\ http://bcsia.ksg.harvard.edu/
}

\section{$\underline{A B O U T T H E A U T H O R}$}

Simon Saradzhyan graduated from the John F. Kennedy School of Government, Harvard University, in 2002 with a Master in Public Administration degree and presently works as news editor at The Moscow Times, an English-language daily in Moscow. His primary research interests are non-proliferation, security, defense and space affairs in the former Soviet Union. 


\section{CO-SPONSORS}

The cosponsors of this report invite liberal use of the information provided in it for educational purposes, given proper citation.

U.S.-Russian Nonproliferation Working Group

Belfer Center for Science and International Affairs

John F. Kennedy School of Government

Harvard University

79 JFK Street

Cambridge, MA 02138

http://www.ksg.harvard.edu/bcsia

Nuclear Threat Initiative

1747 Pennsylvania Avenue NW, $7^{\text {th }}$ Floor

Washington, D.C. 20006

http://www.nti.org

\section{NOTE FROM AUTHOR}

The author would like to thank Professor Graham Allison, director of the Belfer Center for Science and International Affairs, for his insightful guidance and generous advice, Matthew Bunn, assistant director of the Science, Technology and Public Policy Program, Belfer Center for Science and International Affairs for his insightful input and generous advice, Dmitry Kovchegin, research fellow at the Belfer Center for Science and International Affairs, for his advice, and Danielle Lussier, research assistant at the Belfer Center for Science and International Affairs, for her generous advice as well as for editing this paper. 


\section{Introduction}

The likelihood of a catastrophic terrorist attack against Russia is growing, as radical separatists in troubled Chechnya increasingly become more desperate, and security at many of Russia’s civil nuclear facilities remains insufficient. ${ }^{1}$ They have already demonstrated their capability and willingness to inflict massive indiscriminate casualties by organizing an apartment bombing in the southern Russian city of Buinaksk. They have acquired radioactive materials, ${ }^{2}$ threatened to attack Russia's nuclear facilities, ${ }^{3}$ plotted to hijack a nuclear submarine, ${ }^{4}$ and have attempted to put pressure on the Russian leadership by planting a container with radioactive materials in Moscow and threatening to detonate it. ${ }^{5}$ These incidents occurred between 1994 and 1996, during Russia's first

${ }^{1}$ This report will refer to those who believe that acts of catastrophic nuclear terrorism will serve their aims best as "radical separatists," distinct from "conventional separatists," who would limit themselves to guerilla war methods only. I will define "nuclear terrorism" as any of the three following acts: detonation of a nuclear bomb; sabotage of a nuclear facility with the intention of dispersing large quantities of radioactive material; or the dispersal of radiological material by several powerful dirty bombs. I will define "catastrophic nuclear terrorism" as a terrorist attack that would lead to massive casualties, if not wide-scale destruction, such as the explosion of a nuclear bomb.

${ }^{2}$ Chechen fighters removed several containers of radioactive materials from the Grozny branch of Russia's Radon nuclear waste collection enterprise prior to the seizure of the facility by federal troops in January 2000, according to a Russian magazine’s sources in the Russian Ministry of Defense. Yury Gladkevich, "Poshel v Gory” [Into the mountains], Profil Magazine, March 20, 2000, quoted in "Radwaste Reported Removed from Radon Facility in Grozny," by NIS Nuclear Trafficking Database, Center for Nonproliferation Studies, Monterey Institute of International Studies Nuclear Threat Initiative, available at http://www.nti.org/db/nistraff/2000/20000230.htm as of June 19, 2002. 3 Then-Chechen president Dzhokhar Dudayev warned that his fighters might attack nuclear plants in Russia in 1992 to discourage Moscow from trying to counter his republic's independence bid. He issued a similar threat again in 1995 when the military campaign was already underway in the republic. "Dudayev Grozit Perenesti Voinu v Glub’ Rossii," [Dudayev threatens to transfer war into the depths of Russia], Vecherny Chelyabinsk, February 1, 1995.

4 "V Chechne Nashli Plan Zakhvata Rossiiskoi Lodki” [Plan to hijack a Russian submarine found in Chechnya], Lenta.ru, February 4, 2002, available at www.lenta.ru/vojna as of July 4, 2002. Also reported in "Nachalnik Operativnogo Shtaba Maskhadova Gotovil Plan Zakhvata Rossiiskoi Atomnoi Podlodki” [Chief of Maskhadov's operational staff was preparing a plan to hijack Russian atomic submarine], RIA-Novosti, April 25, 2002.

${ }^{5}$ Chechen warlord Shamil Basayev tried to blackmail Russian leadership with a crude radiological device. Basayev threatened to organize undercover attacks with radioactive, chemical, and biological substances against Moscow. See 
military campaign in Chechnya at a time when separatists were so overwhelmed and outmanned they believed that acts of terrorism employing nuclear, biological, and chemical (NBC) materials-if not weapons of mass destruction (WMD) — could be the only way to force Russian troops to retreat from Chechnya.

During Russia's second campaign (which began in the fall of 1999), Chechnya-based radical separatists have planted explosives into tanks filled with chemical substances, scouted Russian nuclear facilities to establish contact with an insider, ${ }^{6}$ and have stolen radioactive metals from a nuclear power plant. ${ }^{7}$ In October 2002, a group of more than 40 Chechen terrorists took more than 700 hostages at a Moscow theater, in order to force President Vladimir Putin to pull Russian troops out of Chechnya. ${ }^{8}$ While these attempts to coerce the Kremlin have failed, this paper will argue that the Kremlin's refusal to concede to separatist demands has contributed to an escalation of motivation among Chechnya-based radical separatists to attempt acts of nuclear terror.

This paper argues that the threat of catastrophic nuclear terrorism is becoming a clear and present danger to Russia. This threat has grown, due to Russia's second campaign in Chechnya, which has cornered separatists to such an extent that they may believe that acts of catastrophic

section III for more details. Grigorii Sanin and Aleksandr Zakharov, "Konteyner Iz Izmailovskogo Parka Blagopoluchno Evakuirovan" [Container has been successfully evacuated from the Izmailovskii park], Segodnya, November 25, 1995.

6 "Tver Region. Captain of A Regiment Which Guards Kalininskaya NPP Is Suspected of Having Supplied Secret Information To Chechens," Regnum, November 19, 2002.

${ }^{7}$ Separatists stole radioactive metals from the Volgodonskaya nuclear power station in the southern region of Rostov between July 2001 and July 2002, according to U.S. nuclear officials. The precise details of the security breach remain unclear, but one unidentified U.S. official said there was the possibility some plutonium was removed together with other radioactive metals. These included cesium, strontium and low-enriched uranium. Nick Paton Walsh, "Russian Nuclear Theft Alarms US," The Guardian, July 19, 2002. See also Section III.

${ }^{8}$ Some 40 terrorists led by Chechen warlord Movsar Barayev, seized a Moscow theater on October 23, 2002, taking more than 700 hostages and demanding the withdrawal of Russian troops from Chechnya. The Kremlin refused to meet 
nuclear terrorism would be the only way to force Russian troops to leave the North Caucasus. The explosion of a nuclear bomb would clearly be the most intimidating of possible catastrophic terrorism scenarios because of the massive casualties, disruption, and psychological impact it would cause. In addition to trying to obtain a nuclear warhead, the radical separatists might also attempt to hijack a nuclear-armed submarine or seize a nuclear facility in order to coerce the Russian leadership into pulling out of Chechnya by threatening to disperse large quantities of radioactive materials.

This paper explains why Russian policy-makers should see catastrophic nuclear terrorism as an imminent threat. It exposes flaws in the existing system of nuclear security in Russia, including a lack of equipment that would prevent and detect theft and trafficking of nuclear materials. It then identifies those groups and leaders within the community of Chechnya-based separatists that have the capability and motivation to take advantage of these flaws and commit acts of catastrophic nuclear terrorism against Russia. The paper will outline the most probable scenarios of how these groups may implement their deadly plans.

The paper also identifies those capable of stealing and selling nuclear materials, as well as those motivated to do so, such as corrupt insiders at nuclear facilities, members of organized criminal groups, and radical separatists. It will argue that the recent cases of conventional thefts in the Russian military demonstrate that some officers may be persuaded to steal and sell weaponsgrade materials, if not nuclear arms, which may end up in the hands of Chechnya-based radical separatists. As their chances in securing an independent Chechen state by conventional means worsen, committing a catastrophic nuclear terrorist attack will become an even more appealing option for them, and the likelihood of such an attack will continue to increase unless Russian leaders act to improve security immediately, not just at the country's nuclear arsenals, but at all facilities that

this demand even though the terrorists threatened to start killing the hostages. See Section III for more details. Natalia Yefimova, “3 Hostage Victims Sue City for \$2.5M,” The Moscow Times, November 27, 2002. 
house NBC materials and components that can be used in the construction of weapons of mass destruction. Finally, in an appendix, the paper offers recommendations on what Russian authorities should do to minimize the possibility of catastrophic nuclear terrorism.

\section{Threat of Nuclear Terror: Why the Kremlin Should Be Concerned}

The disintegration of the Soviet Union left 40,000 nuclear weapons, more than 1,000 metric tons of nuclear materials, vast quantities of chemical weapons and biological materials, and thousands of missiles scattered across several independent states. 'The largest portions of this deadly arsenal were concentrated in Russia, Ukraine, and Kazakhstan, which faced the biggest challenge to secure these materials. Frantic efforts by the Russian and U.S. governments coupled with the good will of the other former Soviet states have brought most of the arsenal to Russia for storage and disposal. However, the decentralized and weak country was initially unprepared to safeguard the stockpiles accumulated by the totalitarian Soviet regime.

The Soviet Union took pains to maintain a strong second line of defense against proliferation of NBC materials by making its borders impenetrable from within and without. ${ }^{10}$ But post-communist democratic Russia can ill afford to build a strong Iron Curtain. Instead Russian authorities have focused on strengthening the first line of defense: security perimeters at nuclear facilities. Considerable improvements in security have been made during the past decade at the Defense Ministry's nuclear facilities, as Russian authorities view the threat of terrorism and proliferation more seriously. Acknowledging the scope of this danger, Russian policymakers have

\footnotetext{
9 “A Report Card on the Department of Energy's Nonproliferation Programs with Russia," the Secretary of Energy Advisory Board, The United States Department of Energy, January 10, 2001, available as of May 13, 2002 at http://www.hr.doe.gov/seab/rusrpt.pdf.
} 
defined terrorism as one of the major threats to the country in both Russia's National Security Concept and Military Doctrine. ${ }^{11}$ Nevertheless, the possibility that terrorists could acquire nuclear materials or even seize a Russian military nuclear facility still exists.

"We are facing a growing threat of the use of nuclear materials by terrorists," deputy head of the $12^{\text {th }}$ Main Directorate of the Defense Ministry General Alexander Frolov told a U.S. newspaper in July 2002." "They may even go so far as capturing nuclear facilities. Among the matters of concern are lack of personnel regulations and the diminishment of military personnel from nuclear facilities. Former workers of our nuclear complex may be the focus of attention for terrorist groups."

The Russian government is taking seriously the threat posed by terrorists to nuclear arsenals and nuclear power plants (NPPs) and acting to secure them, ${ }^{13}$ but it has not focused sufficient

\footnotetext{
10 This approach left no strong need for robust security at the Soviet nuclear facilities as a thief could not have found a buyer for highly enriched uranium (HEU) inside the country, and smuggling anything across the Soviet border was extremely difficult.

${ }^{11}$ Russia's National Security Concept, which was presented in January of 2000, admits that "terrorism represents a serious threat to the national security of the Russian Federation" and that "international terrorism is waging an open campaign to destabilize Russia." The Military Doctrine, which was adopted on April 21, 2000, lists "activities of extremist nationalist, religious, separatist, terrorist movements, organizations and structures," as destabilizing factors. The doctrine also warns of "the expansion of ... terrorism."

12 James Rosen, "Russia Seeks Nuclear Security," The News and Observer (North Carolina), July 8, 2002.

${ }^{13}$ Russian President Vladimir Putin met with Minister of Atomic Energy Alexander Rumyantsev on November 10, 2001, to discuss security at Russia’s nuclear facilities. Two Russian press accounts of the meeting indicate that Putin ordered that security be increased, with expanded guard forces to protect against terrorists. One of these articles reports that the meeting was occasioned by an FSB test of security at one nuclear facility, in which the mock "terrorists" were easily able to break through the security system. "The Ministry of Atomic Energy in the Middle of a Scandal," Nezavisimaya Gazeta, December 14, 2001 (translated by BBC Monitoring Service), and Yuri Golotyuk, "Peaceful Atom Preparing For a War," Vremya Novostei, November 12, 2001. Russia's Rosenergoatom concern planned to invest 2 billion rubles to further increase security at Russian nuclear power plants in 2002. Another 4.2 billion rubles would be invested in 2003-04 even though the level of security was deemed as sufficient by the International Convention on Physical Protection of Nuclear Material International Convention on Nuclear Security in April 2002, technical director of Rosenergoatom Nikolai
} 
attention toward securing the civil facilities that produce, process, and store nuclear materials. ${ }^{14}$ As a result, several cases of theft of HEU and weapons-grade plutonium, dozens of cases of theft of nuclear materials, and even a hostage situation have occurred at the country's nuclear facilities since the disintegration of the Soviet Union.

Despite these breaches, Russian authorities have been reluctant to boost funding for security measures at Russia's civil nuclear facilities. On one hand, the Kremlin's international rhetoric includes nuclear safety, non-proliferation, and the war on terrorism. On the other hand, the Ministry of Atomic Energy and other government agencies have so far failed to upgrade security at a Sorokin told the Interfax news agency on September 5, 2002. "Rosenergoatom Plans to Invest 2 Billion Rubles into Security of NPPs" Interfax, September 2, 2002.

${ }^{14}$ Russia needs at least 6 billion rubles ( $\$ 190$ million) to boost security at its civil nuclear facilities, head of the nuclear safety watchdog Gosatomnadzor Yuri Vishnevsky told reporters in Moscow on November 14. 2002: “This is the minimal sum, which would allow us to bring (security) at a number of nuclear facilities to the level, which meets standards and rules of their physical protection." The official noted that technical protection is outdated at some of the facilities, some of which also lack double physical protection. He also said he is "alarmed by the human factor" in the security infrastructure, but would not elaborate on what has caused his concerns. With security inadequate at some facilities, highly enriched uranium has been repeatedly stolen from Russian nuclear facilities, but the amount of HEU stolen totaled only in grams in any of the cases registered in the past decade, Vishnevsky claimed. "Of those situations that we can talk about in actuality, they involve either grams of weapons-grade or kilograms of the usual uranium used in atomic power plants." Vishnevsky said only the "common, poorly-enriched uranium" has been stolen in kilograms over the same period of time. He said most of the thefts occurred at nuclear fuel production plants, singling out the Novosibirsk and Elektrostal plants. "Gosatomnadzor: Leaks of Nuclear Materials From Atomic Facilities Registered in Russia," Interfax, November 14, 2002. According to the U.S. Department of Energy's Baker-Cutler report, it will cost \$ 5 billion to introduce MPC\&A improvements over the period of 8-10 years. These improvements would include material consolidation, equipment upgrades, training of operators, managers and regulators, computerized inventory systems, upgrading security during transport, etc. Securing excess Russian plutonium and HEU would cost another $\$ 20$ billion, according to this 2001 report. “A Report Card on the Department of Energy's Nonproliferation Programs with Russia," the Secretary of Energy Advisory Board, the United States Department of Energy, January 10, 2001, available 2002 at http://www.hr.doe.gov/seab/rusrpt.pdf) as of May 14, 2002. 
sizeable portion of the civil nuclear facilities to the level recommended by Material Protection, Control, and Accounting (MPC\&A) standards. ${ }^{15}$

While allocating billions of rubles annually for the anti-separatist campaign in Chechnya, the Russian government has been unwilling to spend more money on ensuring that all of Russia's weapons-grade and other nuclear materials are inaccessible to terrorists. According to leading experts on Russian nuclear security, the government remains reluctant to divert its limited resources from such priorities as the Chechen campaign and social expenditures to nuclear security programs. $^{16}$

\footnotetext{
${ }^{15}$ By February 2001, MPC\&A upgrades had been completed only at 81 out of 251 Russian military and civil nuclear sites designated by U.S. Department of Energy as in need for such upgrades. Rapid upgrades had been completed at another 34 facilities, work had begun at another 69 facilities while work was yet to begin at 69 facilities, according to U.S.

General Accounting Office's 2001 report. “Nuclear Nonproliferation: Security of Russia’s Nuclear Material Improving; Further Enhancements Needed,” Report to Congressional Requesters, U.S. General Accounting Office, February 2001. The number of enterprises where the upgrades have been completed could not have increased dramatically since then, according to Alexander Pikayev, senior researcher, Moscow Carnegie Center, interview by author, January 2003. Russia's nuclear security watchdog Gosatomnadzor admits that there are problems with accounting and control. Chief of Gosatomnadzor Yuri Vishnevsky commented that some enterprises still rely on "Aunt Masha keeping a book of whether she has given something to someone or not." Press conference with Yuri Vishnevsky, Moscow, February 21, 2003. According to a book written by Vladimir Kuznetsov, former inspector at the Gosatomnadzor nuclear security watchdog, most of Russian facilities, which house nuclear reactors, lack equipment to detect unauthorized removal of nuclear materials or explosives brought onto the ground of a facility. Most facilities also lack optical-electronic equipment to monitor security perimeters and have no barriers at checkpoints to prevent vehicles from crashing through onto the territory, according to the book. A significant number of facilities lack security services while some of those guarded by security services lease space to commercial companies. Vladimir Kuznetsov, "Nuclear Danger. Main Problems and Present Condition of Security at Enterprises of Nuclear Fuel Cycle of the Russian Federation," Epicenter, Russia, 2003.

${ }^{16}$ Vladimir Orlov, director, PIR Center, Moscow, and Alexander Pikayev, senior researcher, Moscow Carnegie Center, Russia's leading non-proliferation experts, interview by author, April 2002. Yuri Vishnevsky, chief of Russia’s chief nuclear security watchdog Gosatomnadzor, also admits that most of Russia's nuclear facilities are still poorly guarded. Yet, the government agencies do not plan to complete upgrades at these facilities until 2007, which is unacceptable, the official said in a November 2002 interview. "Vtorgsya-Sbivat" [ntruders must be shot down], Gazeta, November 26, 2002.
} 
Ensuring that all of Russia's nuclear materials are secure and accounted for has not become a top priority for the Russian government because some of Russia's policy-makers and bureaucrats believe that security in the form of armed guards and fences is sufficient for civil nuclear facilities and that Russia's security services and law-enforcement agencies would be able to prevent any direct assault on nuclear facilities by terrorists. Also, they believe that it is improbable that anyone who manages to steal HEU or weapons-grade plutonium would sell these materials to individuals who would plot terrorist acts against Russia. ${ }^{17}$ They also believe that Russia faces no imminent threat of nuclear terrorism even if terrorists do get hold of nuclear materials, because they lack the expertise required to build an atomic bomb. These beliefs are so widely held that bureaucrats reflexively screen out evidence to the contrary and suppress potential whistle-blowers within Russia's nuclear hierarchy. $^{18}$

The government's reluctance to boost funding for security at civil nuclear facilities also stems from the argument that Russia can rely on the United States for financial and technical assistance because Washington sees proliferation and theft of WMD as an imminent threat to U.S. national security, and it requires immediate action. Some in Russia's ruling elite do not believe this threat is imminent, and thus prefer to wait rather than act. They hope that the United States and other Western governments will fund the reduction of this threat, according to two prominent nuclear security experts, Ivan Safranchuk and Alexander Pikayev. ${ }^{19}$ They claim that some members

\footnotetext{
17 Orlov Interview, April 2002.

${ }^{18}$ According to Kuznetsov, some reluctant managers of the Russian nuclear industry even deny access to inspectors armed with sophisticated detectors and high-precision control equipment, arguing that their actions could lead to "disclosure of state secrets," according to a former senior inspector of Gosatomnadzor.

${ }^{19}$ Ivan Safranchuk, senior researcher, Center for Defense Information, and Pikayev, interview by author, April 2002.
} 
of the Russian elite think that the United States would not increase its non-proliferation assistance if Russia contributes more of its own funds to deal with the problem. ${ }^{20}$

The June 2002 G8 summit in Kananaskis, Canada supported the Kremlin's stance. The agreement reached at the summit calls on G8 members, excluding Russia, and the European Commission to raise up to $\$ 20$ billion during the next ten years for dismantling decommissioned nuclear submarines, disposing fissile materials, and employing former weapons scientists. ${ }^{21}$ The United States will provide 50 percent of this amount, while the European Union, Japan, and Canada will give the remaining funds. ${ }^{22}$ While the summit's documents do not specify what countries will receive this aid, it is clear that the bulk of it will go to former Soviet republics, including Russia, if the agreement is implemented. ${ }^{23}$

It remains to be seen whether and exactly how much Russia will receive from its G8 partners and the European Commission. It is clear, however, that these billions could significantly reduce the possibility of terrorists acquiring WMD and WMD components if the money is spent in the three following ways: to ensure that all of Russia's NBC materials are safely stored or disposed of; to prevent leaks of WMD technologies, including brain-drain; and to make Russia's currently porous borders more difficult for WMD smugglers to cross.

\footnotetext{
20 Ibid.

21 “The G8 Global Partnership Against the Spread of Weapons and Materials of Mass Destruction," Statement by the Group of Eight Leaders, Kananaskis, Canada, June 27, 2002.

22 "Fact Sheet G-7/8 Kananaskis Summit Day Two - U.S. Accomplishments," Office of the Press Secretary of the President of the United States, June 27, 2002.

23 “Russia: U.S. To Aid Nuclear-Arsenal Cleanup,” RFE/RL, June 28, 2002. Russian Deputy Foreign Minister Georgii Mamedov said in October 2002 that fellow members of the G8 would give Russia \$15 billion. The United States would allocate $\$ 10$ billion while other G8 members would give $\$ 3.7$ billion, and the European Union, $\$ 1$ billion. Another $\$ 5$ billion would come from Russia. In exchange, G8 members would write off $\$ 5$ billion in Russian debt. Aleksei Nikolskii, Elena Evstigneeva, Ekaterina Kudashkina, "Semerka Naskrebla 15 Milliardov” [G7 has raised \$15 billion], Vedomosti, October 23, 2002.
} 
If it accepts this funding, the Russian government will have to abandon its rhetoric that their country faces no imminent threat of nuclear terrorism as long as thieves and terrorists do not have access to nuclear warheads. This rhetoric has persisted even though it no longer takes a group of top-notch academics to assemble a crude nuclear device, as authoritative experts have concluded that nuclear weapons can be constructed with some knowledge of physics and explosives and the ability to manufacture the relevant parts. ${ }^{24}$ A well-organized terrorist group could recruit a combination of experts with such knowledge and ability. The group would then only need to obtain HEU in order to assemble and detonate a simple "gun-type" bomb, ${ }^{25}$ believing that it would cause casualties and damage significant enough to intimidate Russia into pulling out of Chechnya, if not other parts of the North Caucasus, such as Dagestan and Karachayevo-Cherkessia. The culprits may calculate that the Russian leadership will bow to their demands as long as the terrorists are able to produce credible evidence that proves they are capable of detonating another nuclear bomb. The perpetrators may believe that such evidence would prevent Russia from resorting to indiscriminate methods of massive retaliation, given the fact that radical separatists have no exact return address, as they often hide in Chechen settlements formally controlled by Russian troops.

On the other hand, it is impossible to predict how a nation injured and enraged by a nuclear strike would act. Russian authorities might encircle suspected terrorist hideouts and flatten them,

\footnotetext{
${ }^{24}$ J. Carson Mark, Theodore Taylor, Eugene Eyster, William Maraman, and Jacob Wechsler, “Can Terrorists Build Nuclear Weapons?" in Paul Leventhal and Yonah Alexander, eds., Preventing Nuclear Terrorism (New York: Lexington Books, 1987), available as of May 13, 2002 at http://www.nci.org/k-m/makeab.htm.

${ }_{25}$ Matthew Bunn, John P. Holdren, and Anthony Wier, "Securing Nuclear Weapons and Materials: Seven Steps for Immediate Action," Project on Managing the Atom, Belfer Center for Science and International Affairs, John F. Kennedy School of Government, Harvard University, May 2002, available at http://www.nti.org/e research/securing nuclear weapons and materials May2002.pdf as of June 24, 2002.
} 
possibly obliterating all of Chechnya. Russia's former atomic energy chief Viktor Mikhailov thinks that Chechnya would be entirely destroyed if Chechen separatists try to detonate a dirty bomb. ${ }^{26}$

Fortunately, there is no credible public information that Chechnya-based radical separatists presently possess either a nuclear bomb or the expertise to assemble one. This does not mean, however, that they and their allies in Islamist terrorist organizations like al-Qaeda and in regimes similar to the Taliban will not be able to acquire nuclear weaponry expertise in the future. ${ }^{27}$ In 2000 , it was reported that the Taliban sought to recruit a Russian nuclear expert. ${ }^{28}$ Al-Qaeda has tried to acquire a ready-to-use nuclear bomb or to develop one, and has considered striking a deal with

26 "If Chechen rebels try to seize a nuclear power station or decide to disperse radioactive materials to contaminate air and war, this would be equivalent to declaring a nuclear war against Russia.... The response will be very tough for Chechens," Russia's former atomic chief Viktor Mikhailov was quoted as saying in the December 4, 2002 issue of Izvestia. "The rebels must realize that their entire people will bear responsibility for their actions. Chechens engage into nuclear blackmail, there will be no Chechnya left on the Earth." Alexander Khokhlov, "Viktor Mikhailov, Byvshii Ministr Po Atomnoi Energii: Esli Chechentsy Zaimutsya Yadernym Shantazhom, Chechni Na Zemle Ne Ostanetsya” [Viktor Mikhailov, former atomic energy minister: if Chechens engage in nuclear blackmail, there will be no Chechnya left on the earth], Iqvestia, December 4, 2002.

${ }^{27}$ George Tenet, Director of the Central Intelligence, stressed in a February 6, 2002 testimony before the U.S. Senate Select Committee on Intelligence that terrorist groups worldwide have ready access to information on chemical, biological, and even nuclear weapons via the Internet, and that "we know that al-Qaeda was working to acquire some of the most dangerous chemical agents and toxins." According to Tenet, documents recovered from al-Qaeda facilities in Afghanistan showed that Bin Laden was pursuing a sophisticated biological weapons research program and that the US believed that Bin Laden was seeking to acquire or develop a nuclear device. Moreover, he added, "al-Qaeda may be pursuing a radioactive dispersal device - what some call a 'dirty bomb." Quoted in Karl A. Lamers, "Draft Report on Arms Control And The Transatlantic Partnership After September 11," Political Sub-Committee On Transatlantic Relations, NATO Parliamentary Assembly, May 3, 2002, available at http://www.natopa.int/publications/comrep/2002/av-112-e.html as of July 4, 2002.

28 On October 6, 2000, at a conference on nuclear non-proliferation in Moscow, Russian Security Council official Raisa Vdovichenko reported that Taliban envoys had sought to recruit at least one Russian nuclear expert. While the recruiting target did not agree to work for the Taliban, three of his colleagues had left his institute for foreign countries and Russian officials did not know where they had gone. RFE/RL, October 9, 2000. 
members of Russian organized criminal groups. ${ }^{29}$ Chechnya-based terrorists can also hope that alQaeda, which maintains ties with the Islamist strain of radical separatists in the North Caucasus and has had Chechen members, will supply them with nuclear weapons for a jihad against Russian infidels if it manages, for instance, to topple the government of Pakistan. ${ }^{30}$ Therefore, Russian authorities must do everything in their capacity to fill all holes in the country's nuclear security fences before terrorists acquire the capability to build a nuclear bomb. Otherwise, given the existing

29 "We also believe that [al-Qaeda leader Osama] bin Laden was seeking to acquire or develop a nuclear device," George Tenet, Director of the Central Intelligence, told hearings at the U.S. Congress in February 2002. In his testimony, Tenet refrained from disclosing where al-Qaeda operatives could be shopping for such technology. "Worldwide Threat Converging Dangers in a Post 9/11 World," testimony of Director of Central Intelligence George Tenet before the Senate Select Committee on Intelligence, February 6, 2002. Al-Qaeda may be trying to acquire nuclear weapons and weapons-grade materials in Russia through local organized crime gangs, Washington Times reported, citing a source in the U.S. defense community. Bill Herz, “U.S. says al-Qaeda exploring Russian market for weapons,” The Washington Times, October 8, 2002.

${ }^{30}$ There have been numerous reports about links between Chechen separatists and al-Qaeda. Some noteworthy examples include: (1) U.S. charge d'affaires in Tbilisi Philip Remler suggested in February 2002 that the Chechen contingent in Georgia's Pankisi gorge could include individuals with ties to al-Qaeda, "Georgian Defense Minister Doubts Al-Qaeda In Pankisi," RFE/RL, May 10, 2002, available at http://www.rferl.org/newsline/2002/05/2TCA/tca-100502.asp as of July 14, 2002. (2) U.S. intelligence agencies have estimated that as many as 100 al-Qaeda militants joined hundreds of Chechen fighters who set up base in Georgia’s troubled Pankisi gorge. Peter Baker, “Arab Militants Turned Over to U.S. by Georgian Forces,” The Washington Post, October 21, 2002. (3) The FBI also believes there are ties between Chechen separatists and al-Qaeda. "Although al-Qaeda functions independently of other terrorist organizations, it also functions through some of the terrorist organizations that operate under its umbrella or with its support, including: the Al-Jihad... and the Chechen region of Russia." J. T. Caruso, Acting Assistant Director, Counter Terrorism Division, Federal Bureau of Investigation, Statement for the Record on Al-Qaeda International Before the Subcommittee on International Operations and Terrorism Committee on Foreign Relations, United States Senate, Washington, D.C., December 18, 2001, available at http://www.fbi.gov/congress/congress01/caruso121801.htm as of July 14, 2002. (4) There have been reports of Chechens fighting on the al-Qaeda side in Afghanistan. Two Chechen members of al-Qaeda were killed in a gun-battle with Pakistani troops in Azam Warsak, a remote tribal area of Pakistan bordering Afghanistan on June 26, 2002, unidentified Pakistani officials said. The same area saw Pakistani security officials capture a Chechen, identified as Muhammad Yahya, also in June, the officials said. M. Ismail Khan, "10 Soldiers, Two Fugitives Killed: Al-Qaeda Hideout In Tribal Area Raided,” Dawn, June 27, 2002. 
opportunities for theft of weapons-grade nuclear materials, Russia could suffer a nuclear explosion as soon as terrorists acquire the necessary expertise.

\section{Agents of Nuclear Terrorist Threats to Russia}

Incidents of terrorism in Russia are often linked to instability in the North Caucasus. To date, separatist groups in this region have committed acts of conventional terrorism only. Most of these groups and their leaders, such as Ruslan Gelayev, seem to have no interest in WMD. They believe that their conventional attacks generate sufficient casualties to keep Russia bleeding, and that Russian troops will withdraw sooner or later. Their attacks also generate enough publicity to ensure the international community remains aware of their struggle.

However, as this paper seeks to prove, some Chechnya-based separatist leaders, who have held high posts in the de-facto independent Chechen republic of Ichkeria, are starting to lose confidence in their belief that Russia can be forced to leave gradually. These radical separatist leaders are losing their patience, and their groups are plotting nuclear terrorist attacks. It may be only a matter of time before they decide to implement their plans. ${ }^{31}$

Former prime minister of separatist Chechnya, Shamil Basayev, represents the particularly fanatical Islamist strain of separatism in the North Caucasus, which is mostly concentrated in Chechnya. These Islamist radicals, often incorrectly referred to as wahabbis, are mostly militant

\footnotetext{
31 Two "reconnaissance and sabotage groups" of Chechen rebels "displayed interest" in how nuclear arms are transported across Russia in 2001. Rossiiskaya Gazeta reported that the groups were spotted at several key railway stations in the Moscow region, and "They seemed to have been very interested in the special train, which is designed for shipping atomic bombs." One group of Chechnya-based radical separatists cased the Moscow-based Kurchatov Institute, which houses several research reactors in 2002. The group, which was led by Movsar Barayev and which seized a Moscow theater on October 23 only to be overwhelmed by Russian commandos less than 60 hours later, had planned seizure of one of the Kurchatov Institute's reactors. Vladimir Bogdanov, "Propusk K Boegolovkam Nashli U Terrorista" [A pass to warheads found on a terrorist], Rossiiskaya Gazeta, November 1, 2002.
} 
salafites who seek to establish an Islamist state that would include all Muslim republics of the North Caucasus. $^{32}$

Basayev has tried to blackmail Russian leadership with a crude radiological device in the past. In 1995, this salafite-oriented warlord threatened to organize undercover attacks with radioactive, chemical, and biological substances against Moscow and other strategic sites in Russia unless July peace negotiations were successful. "We have radioactive elements, biological weapons that Russia left us," he said. The rebel commander warned that he could send a shakhid (kamikaze) to plant uranium in a Russian city. "Putting uranium in Moscow requires one person. One person gets killed and the city dies."33

The July 1995 peace talks failed and Basayev told the media that his agents had smuggled five packages into Moscow and that at least two of them contained dirty bombs. On Novemeber 23, 1995, a Russian TV crew found a lead container with radioactive cesium-137 in Moscow's Izmailovskii park. ${ }^{34}$

However, Basayev never followed through on his threats to detonate the bombs, even though a peace deal was not clinched until August 1996. It remains unclear why Basayev failed to detonate the containers. His plans may have been foiled by security measures taken by Moscow lawenforcers upon finding the first container. Basayev may have also been bluffing. Perhaps he calculated that the impact from the explosion of a dirty bomb would not be sufficient to compel the

\footnotetext{
${ }^{32}$ Salafites are Islamists who stand for Salafiya, which means "pure Islam.” Many ascribing to Salafism support radical actions in search of this pure Islam. It should be made clear that only a part of salafites in the North Caucasus is militant and ready to use force in order to establish an Islamist state. Only 1,000 out of 21,000 salafites in Dagestan were militant as of 2000. Alexei Malashenko, "Islamic Factor in the Northern Caucasus," Gendalf, Moscow, 2001, available at http://pubs.carnegie.ru/books/2001/03am as of July 14, 2002. has been successfully evacuated from the Izmailovskii park], Segodnya, November 25, 1995.
} 
Kremlin to concede to a peace deal, but may have been outrageous enough to cause a massive crackdown in those parts of Chechnya where the presence of rebels was felt strongly. ${ }^{35}$

Basayev resumed his attempts to put pressure on the Kremlin after the start of Russia's second military campaign in Chechnya, and he ordered the October 2002 attack on a Moscow theater. After this attack failed to compel Russia to withdraw from Chechnya, Basayev gave up his operative control of Chechen separatist forces and said he would concentrate on running the Riyadus-Salikhin shakids battalion. ${ }^{36}$ As commander of this unit, he wrote an open letter to NATO leaders in November 2002 warning of new strikes in Russia if its troops were not pulled out of Chechnya. ${ }^{37}$ Russia's Federal Security Service (FSB) has classified Basayev's Riyadus-Salikhin unit as one of the country's most dangerous terrorist organizations. ${ }^{38}$

In the past, Aslan Maskhadov, who was elected president of separatist Chechnya in January 1997, has tried to position himself as a secular moderate who disapproves of religious fanaticism.

35 “'A radiological 'dirty bomb,' which would just spread radioactive material over an area, is really a weapon of mass disruption more than a weapon of mass destruction. By forcing the evacuation of many blocks of a city, it could potentially cause billions of dollars in economic disruption, and billions more in cleanup costs, but it would not kill tens of thousands of people in a flash or obliterate a major section of a city as an actual nuclear bomb could." "Radiological 'Dirty Bombs,"' Project on Managing the Atom, Belfer Center for Science and International Affairs, John F. Kennedy School of Government, Harvard University, available at http://ksgnotes1.harvard.edu/BCSIA/MTA.nsf/www/NTerror\#dirtybomb as of June 20, 2002. Also, as former director of Central Intelligence John Deutch pointed out, a terrorist radiological dispersal attack could cause damage to property and the environment, and cause societal and political disruption. "The Threat of Nuclear Diversion," Statement for the Record by Director of Central Intelligence John Deutch, Global Proliferation of Weapons of Mass Destruction, Part II, hearings before the Governmental Affairs Committee, Permanent Subcommittee on Investigations, U.S. Senate, 104th Congress, 2nd Session, March 1996.

${ }^{36}$ Nabi Abdullaev, “Basayev Says Raid Was on His Orders,” The Moscow Times, November 4, 2002.

37 "We are also warning that all military, industrial and strategic facilities on the territory of Russia are legitimate military targets for us, whomever they may belong to," Basayev said. "Basayev Says His Rebels Will Launch New Strikes," Reuters, November 25, 2002.

38 The service's spokesman Sergei Ignatchenko told a Russian news agency in February 2003 that the Riyadus-Salikhin unit is on the FSB's "list of organizations that cause most damage to the security of Russia" along with al-Qaeda and the 
More recently, however, Maskhadov has moved closer to the Islamist fundamentalist wing of radical Chechen separatists. In 1996, Maskhadov signed the Khasavyurt peace accord with the Kremlin and repeatedly called for peace talks during Russia's second campaign in Chechnya. But more recently, Maskhadov has allegedly authorized terrorist attacks against Russia, including the October 2002 hostage-taking in Moscow. ${ }^{39}$ Russia's state-run television also claimed that Maskhadov has approved a plan to use a nuclear weapon to blackmail the Kremlin, although no independent source confirmed this claim. ${ }^{40}$

Maskhadov transferred the operative control of Chechen separatist forces Shamil Basayev in July 2002. ${ }^{41}$ In September 2002, a videotape surfaced which showed Maskhadov abandoning his

Congress of the Peoples of Ichkeria and Dagestan. Basayev co-leads this congress. "FSB Calls Basayev's Batallion of Kamikaze One of the Most Dangerous Terrorist Structures," Interfax, February 7, 2003.

${ }^{39}$ Maskhadov condemned the hostage-taking in a statement published on October 26, 2002 on the official rebel web site, Chechenpress.com, and denied having anything to do with the attack. However, Sunday Times reporter Mark Franchetti, who interviewed Movsar Barayev, leader of the October 2002 hostage takers, said Barayev told him the attack had been a joint operation with Chechen warlord Shamil Basayev and Chechen president Aslan Maskhadov. Nabi Abdullaev. "Barayev Points Finger at Basayev," The Moscow Times, October 28, 2002.

Also Russian State Duma Boris Nemtsov said that he learned that Maskhadov had been behind the hostage-taking during his negotiations with Barayev. Nemtsov also said that the fact that Maskhadov denied any role in the organization of the hostage-taking raid only after it was over seemed suspicious to him. "Nemtsov Calls For Round Table on Chechnya, But Without Terrorists," Interfax, October 28, 2002.

40 The Federal Security Service (FSB) seized tapes of Chechen president Aslan Maskhadov's messages to field commanders in April 2002. In these messages Maskhadov authorized terrorist acts, according to Ilya Shabalkin, spokesman for federal troops in Chechnya. The tapes were found in Chechnya during an operation to arrest chief of the operational department of the Chechen separatists' general staff Islam Khasukhanov in the Chechen town of Shali on April 21, 2002. Yevgeny Sobetskiy, "Russian Military Says Seized Tapes Show Chechen Leader Ordered Terrorist Acts," ITAR-TASS, July 4, 2002. See also Section III.

${ }^{41}$ Maskhadov and Basayev met to arrange this transfer. Their meeting was videotaped and posted on the Chechen separatist web site htpp://www.kavkaz.org on July 22, 2002. Basayev gave up operative control of the Chechen rebels at the end of October 2002 after claiming responsibility for ordering the hostage-taking at a Moscow theater. Nabi Abdullaev, "Basayev Says Raid Was on His Orders, “ The Moscow Times, November 4, 2002. 
regular combat fatigues for paraphernalia of a militant Islamist. ${ }^{42}$ Even prior to this, the U.S. State Department criticized Maskhadov for embracing Islamist fundamentalism and terrorism. ${ }^{43}$ By allying himself with the Islamist wing of radical separatism, Maskhadov shed his image of a moderate and demonstrated his readiness to act together with Islamists to attempt to force Russia into withdrawing from Chechnya by means of nuclear coercion, if not actually engage in acts of catastrophic nuclear terrorism.

In addition to Basayev and Maskhadov, there are other separatist warlords in the North Caucasus who have not hesitated to order terrorist acts, like the bombing of an apartment building in Buinaksk or a holiday celebration event in Kaspiisk, which killed dozens, including children. Beyond Chechnya, groups of militant salafites have been especially strong in the North Caucasian republics of Karachayevo-Cherkessia and Dagestan. Perhaps the best-known militant salafite group of Dagestan is the Islamist Dagestani Jamaat, which is led by Bagauddin Muhammad and has cells in mountainous areas of Dagestan. Bagauddin even once declared that his organization is in a state of war with the Dagestani authorities. ${ }^{44}$ Other well-known leaders of separatists in Dagestan are Rapani Khalilov, Dzharulla Radzhabbadinov, and Adallo Aliyev. Aliyev served as deputy chairman

\footnotetext{
${ }^{42}$ On the tape, which was shown on Russia's Rossiya television channel on September 29, 2002, Maskhadov wore epaulets with verses from the Koran. The tape showed the Chechen leader sitting in front of a green flag, which featured an Arabic sword and Koranic verses rather than a wolf, which has been the symbol of Chechen independence in both first and second Chechen wars.

${ }^{43}$ John Evans, director of the U.S. Department of State's Russia office, told a conference in Berlin on September 9 , 2002, that in recent months Maskhadov has begun to "embrace jihad elements and terrorists." Pavel Felgenhauer, "Russia: Is Putin Ready To Bargain,” The Moscow Times, September 19, 2002.

44 The declaration was made at a meeting of Dagestan's salafite leaders and Chechen warlords in the Chechen city of Gudermes in 1998. This organization's prime goal is establishment of an Islamist state in Dagestan through a gazavat [holy war] against both Russia and Islamist traditionalists in Dagestan. Alexei Malashenko, "Islamic Factor in the Northern Caucasus," Gendalf, Moscow, 2001, available at http://pubs.carnegie.ru/books/2001/03am as of July 14, 2002.
} 
of the so-called Congress of the Peoples of Chechnya and Dagestan ${ }^{45}$ and Khalilov allegedly ordered the May 2002 blast in the Dagestani city of Kaspiisk, which killed 43 and wounded $170 .{ }^{46}$ As for Dzharulla, he was the leader of wahabbis in the Dagestani village of Karamakhi. He declared this settlement an independent Islamist zone in 1998, evicting all representatives of Dagestani authorities. Dzharulla, who maintained close relations with the late Chechnya-based radical separatist leader Khattab, led the resistance of Karamakhi’s wahabbis against federal troops in 1999, but eventually had to flee to Chechnya. ${ }^{47}$

Separatists in Dagestan and other parts of the North Caucasus maintain close ties with their Chechen counterparts. There have been numerous cases where natives of neighboring republics have fought against federal troops on the Chechen side. ${ }^{48}$ Ties are sufficiently strong between salafites of Chechnya and Dagestan that they even formed the Congress of the Peoples of Chechnya and Dagestan, electing Chechen warlord Basayev as their chairman in $1998 .^{49}$

${ }^{45}$ Sanobar Shermatova, "Do Kontsa Voiny V Dagestane Esche Daleko" [The war in Dagestan is still far from the end], Moskovskie Novosti, September 6-13, 1999.

46 “Genprokuratura: Minu Dlya Terakta v Kaspiiske Prodali Voyennye Iz Buinakska” [General Prosecutor's office: the mine for the terrorist act in Kaspiisk sold by the military from Buinaksk], Lenta.ru, June 24, 2002, available at http://lenta.ru/terror/2002/06/24/names/ as of July 4, 2002.

47 “Obshchina Radikalnykh Musulman Dagestana Glazami Ochevidtsa” [The community of radical Moslems of Dagestan through the eyes of an eyewitness], Nezavisimaya Gazeta, November 10, 1999.

48 There were 500 Salafites in Karachayevo-Cherkessia alone as of 2000, according to estimates of the Federal Security Service. As for Dagestan, there were 1,000 militant salafites in this republic as of 2000. Dozens, if not hundreds of men trained in salafite camps in different republics of the North Caucasus have joined Chechen separatists. Bagauddin Muhammad of the Dagestani Islamist Jamaat had close ties with the late Chechnya-based warlord Khattab. He also helped to draft Chechnya's Sharia laws in 1997. Alexei Malashenko, Islamic Factor in the Northern Caucasus, Gendalf, Moscow, 2001, available at http://pubs.carnegie.ru/books/2001/03am as of July 14, 2002.

49 The second meeting of this congress saw delegates from salafite communities of Chechnya and Dagestan demand "decolonization" of the North Caucasus and withdrawal of Russia from the region. Basayev not only became chairman of this congress in April, but also declared himself "the emir of the Islamist State of Dagestan" during the incursion of militant salafites from Chechnya into Dagestan in 1999. Malashenko, ibid. 
Militant salafites from the North Caucasian republics have fought in both Chechen wars and participated in the 1999 incursion of separatists from Chechnya into Dagestan under the command of Basayev and Khattab. According to Shamil Beno, former Moscow envoy under head of the Chechen government Akhmad Kadyrov, Dagestanis accounted for more than 80 percent of the rebels who took part in the botched incursion. ${ }^{50}$

Despite setbacks dealt by Russian troops and law-enforcers, the militant strain of Islamic fundamentalism remains a formidable presence in Chechnya and other parts of the North Caucasus, drawing followers mostly from local provinces as well as from Muslim republics in central Russia and from abroad. ${ }^{51}$ While these groups have not displayed a strong interest in acquiring WMD, they have contacts with Chechnya-based radical separatists and might choose to assist them in the execution of catastrophic nuclear terrorist attacks.

Chechen President Aslan Maskhadov has no control over a significant portion of these radical separatist groups. Despite his claims to the contrary, Maskhadov and his loyalists can do little but coordinate occasional joint operations inside Chechnya. Moreover, rival leaders regularly challenge Maskhadov's presidential status. ${ }^{52}$ The radical separatists who are beyond Maskhadov's control may eventually stage independent attempts to carry out acts of catastrophic nuclear terrorism

\footnotetext{
${ }^{50}$ Beno was quoted as making this estimate in Andrei Smirnov, “Terrorism: Vzryvy/Vtoroi Front Chechenskikh Boevikov" [Terrorism: explosions/second front of Chechen rebels], Grani.ru, January 21, 2002, available at http://www.grani.ru/blast/articles/lorry/ as of July 10, 2002.

${ }^{51}$ Dagestan's Islamist radicals suffered a major setback when federal troops crushed the self-proclaimed Islamist independent zone in Dagestan's Buinaksk district. The local salafites declared "Islamist territory ruled by the Sharia law" in four settlements of Dagestan's Buinaksk district, known as the Kadar zone, in 1998. Russian troops managed to overtake the villages in August 1999. After their defeat in the Kadar zone, Dagestan's salafites have gone underground and are presently "nowhere, but everywhere." Vladimir Bobrovnikov, "Islam in the Post-Soviet Northern Caucasus (Dagestan): Myths and Reality" in Islam in the Post-Soviet Newly Independent States: The View from Within, edited by Alexei Malashenko and Martha Brill Olcott, Moscow Carnegie Center, Moscow, July 2001.

52 "Brigadny General Arsanov Prosit Maskhadova Uiti V Ostavku” [Brigadier General Arsanov asks Maskhadov to resign], July 9, 2002, Lenta.ru, available at http://www.lenta.ru/vojna/2002/07/09/arsanov/ as of July $12,2002$.
} 
even if he specifically orders all Chechen rebels to refrain from such an attack. Fortunately, there is no evidence that Chechnya-based radical separatist groups possess nuclear bomb know-how or ready-to-use WMD devices.

\section{Capability to acquire and use}

Of all extremist groups plotting and executing acts of terror against Russia, Chechnya-based terrorist groups have the strongest capabilities to acquire and use NBC materials, if not WMD devices. In addition to having well-trained fighters, shakhids, ${ }^{53}$ and formidable experience in conventional terrorism, the separatists have the further potential advantage of collaborating with both Chechen organized crime networks inside Russia and terrorist networks outside the country. ${ }^{54}$

Chechen organized criminal groups operate in many major Russian cities. In one instance an alleged Chechen criminal was even found to have access to the "closed settlements" inhabited by the personnel of a Russian nuclear production facility. ${ }^{55}$ In another instance an insider at a Russian

\footnotetext{
53 There have been entire units manned with shakhids in the Chechen separatist movement. One such unit was commanded by Adam Bibulatov during the first Chechen war, according to Bibulatov himself. "Ispoved Smertnika o Maskhadove, Basaeyve i Berezovskom" [Testimony of Kamikaze about Maskhadov, Basayev and Berezovsky], Rossiiskaya Gazeta, July 5, 2002.

54 Then head of the Federal Security Service’s Moscow area directorate Yevgeny Savostyanov stated in May 1992 that the Chechen organized crime grouping is the largest and most influential in the Moscow area and that it had 400 "soldiers." “Chechenskoe OPG” [Chechen organized crime grouping], htpp:// www.compromat.ru, 1999. The author found no recent official estimates on Chechen criminal rings.

${ }^{55}$ Law-enforcers in the Sverdlovsk region arrested three Chechens who had been allegedly trying to sell weapons and explosives in March 2002. Police found a valid pass to a high security settlement where workers of a local nuclear facility reside on one of the arrested individuals. Roman Tarsukhanov could have used his pass to enter the settlement of Lesnoi, but would not have been able to access the local facility where nuclear warheads are manufactured. A subsequent search of the arrested individual's apartment revealed more weapons, a remote-control bomb, and Chechen
} 
nuclear power plant was arrested on suspicion that he may have supplied information about this facility to Chechen rebels.

In some instances, those involved in Chechen organized crime rings inside Russia have returned to their homeland to fight on the separatists' side. These gangsters can potentially take advantage of established criminal channels to help the Chechnya-based radical separatists acquire NBC components and organize terrorist acts. ${ }^{56}$ Some organized crime and terrorist gangs have already begun to merge, according to a senior Russian police official. ${ }^{57}$

However, most Chechen ganglords who have settled in Russian cities are unlikely to assist in the organization of a catastrophic nuclear terrorist attack unless they are fanatically dedicated to the

president Aslan Maskhadov's book titled Honor is More Valuable Than Life. Sergei Avdeyev, "Chechens Gain Access to Nuclear Warheads," Izvestia, March 22, 2002, available at http://www.therussianissues.com/topics/53/02/03/22/13892.html as of July 4, 2002.

56 The Federal Service of Tax Police estimated that most of the financing for Chechen rebels comes from Chechen organized criminal groups, which controlled more than 2,000 private companies and banks across Russia in 1999. Rossiiskaya Gazeta quoted deputy director of this service Aslanbek Khaupshev on November 20, 1999 as saying that dozens of companies that Chechens control in Moscow alone were involved in laundering money, some of which went to finance Chechen separatism. One scheme, which was exposed by the Russian tax police, provided for oil to be shipped from primitive oil refineries in Chechnya to be illegally sold through a firm in neighboring Dagestan. The refineries were owned by Chechnya-based warlords Shamil Basayev and Khattab. By the end of 1999 the tax police had ruptured "illegal channels of financing" that were set up by Chechen organized crime groups in Primorskii Krai, Astrakhan, Novgorod and Lipetsk regions. The police also exposed twelve companies owned by the so-called wahabbis in Karachayevo-Cherkessia. Timofei Borisov, "Ekh Dollary, Da Na Tarelochke" [Dollars on the plate], Rossiiskaya Gazeta, November 20, 1999, available at http://www.rg.ru/anons/arc 1999/1120/44.htm as of July 14, 2002. HozhAhmet Nuhayev is one of the prominent Chechen figures who has combined participation in organized crime with separatism. While still a student at Moscow State University, Nuhayev helped to organize an illegal group for the liberation of Chechnya. In an interview with the German "Die Woche," Nuhayev described how he formed a group of reliable and tough Chechens in the late 1980s to offer Moscow businessmen protection in exchange for acceptance of the Chechens as legitimate business partners. In 1994, Nuhayev was indicted by the federal authorities for extortion and fled Moscow for Chechnya where Dudayev, then president of Chechnya, offered him the position of counterintelligence chief, which Nuhayev accepted. "Profile, Hozh-Ahmet Nuhayev," RFE/RL, August 24, 2001, available at http://www.rferl.org/businesswatch/2001/08/7-240801.asp as of July 5, 2002.

57 “Interior Ministry Sees Organized Crime Merge With Terrorist Groups," Interfax, November 14, 2002. 
idea of Chechen independence, because it is likely that their plan would backfire, as law-enforcement agencies would certainly do their best to hunt down all accomplices in a WMD terrorist attack and dismantle their associated gangs.

North Caucasus-based separatists have more than once tried to infiltrate law-enforcement agencies in the region to work as double agents. ${ }^{58}$ They may have also tried to recruit insiders in the Russian nuclear industry as the arrest of a nuclear power plant guard in the Tver region demonstrated. In October 2002, the FSB detained a serviceman of a special unit that was guarding the Kalininskaya nuclear power plant in the Tver region. The suspect served as a captain in his unit and FSB agents found a map which identified all of the plant's "secret facilities," as well as a list of coded phone numbers on the officer, Regnum news agency reported. When FSB agents decoded the phone numbers, they found they belonged to "natives of Chechnya." The agency said that the arrest of the captain, whose identity has not been released, coincided with the storming of the Dubrovka theater in Moscow. ${ }^{59}$

In another instance Chechnya-based radical separatists claimed to have placed a shakhid on a Russian atomic submarine. Soon after the sinking of the Kursk submarine in August 2000,

\footnotetext{
${ }^{58}$ Russian law-enforcers arrested four Chechens for allegedly organizing a car bombing that killed twenty-one in the Chechen village of Alkhan-Yurt in December of 2000. The law-enforcers found that one of the four suspects carried a valid identification card, which identified him as a member of Chechnya's pro-Russian special police force (OMON). This ID proved “aspirations of the Chechen rebels to infiltrate the law-enforcement agencies," Chechnya's then prosecutor Vsevold Chernov said. Ilya Maksakov, "Eskaltsia Terrora v Chechne” [Escalation of terror in Chechnya], Nezavisimaya Gazeta, December 14, 2000. The command of Russian troops in Chechnya announced on July 4, 2002 that several members of Basayev's group were prevented from joining the Chechen OMON. All these members were exposed and arrested, a source in the command said. There have been several cases in the past several months when Chechen policemen assisted the rebels, according to the source. "Boeyviki Shamilya Basayeva Pytalis Zapisatsya V Chechenskii OMON" [Shamil Basayev's rebels tried to join the Chechen OMON], Lenta.ru, July 4, 2002, available at http://www.lenta.ru/vojna/2002/07/04/guerillas/ as of July 5, 2002.

59 “Tver Region. Captain of A Regiment Which Guards Kalininskaya NPP Is Suspected of Having Supplied Secret Information To Chechens," Regnum, November 19, 2002.
} 
separatists claimed it was the work of a Dagestani shakhid, but produced no proof. Law-

enforcement officials claim that neither of the two ethnic Dagestanis on board the Kursk could have deliberately sank the sub. ${ }^{60}$

There have also been instances of mass disobedience by conscripts in the Russian armed forces. Although no cases of subversion in power agencies have been linked to individuals with connections to terrorist groups, it is important to note that many members of separatist groups based in the North Caucasus have previous experience in the Russian and Soviet military that could provide them with useful expertise in staging attacks. ${ }^{61}$

Proof of capabilities. As the incident involving the container of cesium-137 in Izmailovskii park demonstrated, Chechnya-based radical separatists have the capability to covertly deploy an object requiring less sophisticated equipment to detect than an encased nuclear bomb in a Russian city. This incident also showed that these radical separatists possess most of the materials needed to assemble a crude radiological weapon. They have no shortage of the conventional explosives needed to disperse the radioactive material they possess.

\footnotetext{
60 There were two employees of Dagestan's Dagdiesel plant on board of the Kursk when it sank in an accident that was triggered off by an explosion of a faulty torpedo. Dagdiesel designed propulsion systems for Shkval torpedoes carried by Russia's Oscar-II class nuclear submarines, to which the Kursk belonged. Employees of this enterprise regularly attend test firing of torpedoes from Russian atomic submarines. Another native of Dagestan was also on board the submarine as a staff torpedoman. Anna Badkhen and Simon Saradzhyan, "Investigation Opened Into Sinking of Kursk," The Moscow Times, August 25, 2000, available at http://www.themoscowtimes.com/stories/2000/08/25/013.html as of June 14, 2002.

61 "Russia has its own specific conditions that could facilitate carrying out of terrorist acts," argued a recent book on catastrophic terrorism edited by Alexander Fyodorov, senior researcher and officer of Russia's Foreign Intelligence Service. "For instance, until recently, units guarding many military facilities have been comprised of servicemen who were natives of the Caucasus.... Many natives of the Caucasus (including Chechens) who once served at nuclear facilities are familiar with the regime of security there and loopholes that allow for unsanctioned access to these
} 
Sources in the Russian Ministry of Defense have told a Moscow magazine that Chechen rebels had removed several containers of radioactive materials from the Grozny branch of Russia's Radon nuclear waste collection enterprise prior to the seizure of the facility by federal troops in January 2000. ${ }^{62}$ Most recently, Chechen separatists are believed to have acquired nuclear materials from a nuclear power plant in southern Russia. Radioactive metals were stolen from the Volgodonskaya nuclear power station in the southern region of Rostov between July 2001 and July 2002, according to U.S. nuclear officials. The precise details of the security breach remain unclear, but one U.S. official said that some plutonium could have been removed along with other radioactive metals. ${ }^{63}$ These included cesium, strontium, and low-enriched uranium.

\section{Motivation to acquire and use}

Chechnya-based radical separatists are increasingly inclined to stage acts of catastrophic nuclear terrorism against Russia. Before October 2002, they could rely on precedent set in two cases during the first Chechen war as proof that even one successful conventional attack could tie the hands of Russian commanders. Moreover, the first war showed that a similar attack could push

facilities." Megaterrorism: The New Challenge of the New Century, edited by Alexander Fyodorov, Izdatelstvo "Prava Cheloveka" (Publishing House "Human Rights"), Moscow, 2002.

${ }^{62}$ Yury Gladkevich, "Poshel v Gory (Into the Mountains,)" Profil, March 20, 2000, quoted in "Radwaste Reported Removed from Radon Facility in Grozny” by NIS Nuclear Trafficking Database, Center for Nonproliferation Studies, Monterey Institute of International Studies Nuclear Threat Initiative, available at http://www.nti.org/db/nistraff/2000/20000230.htm as of June 19, 2002.

${ }^{63}$ The U.S. source said the theft was reported by Russian officials to the International Atomic Energy Agency (IAEA), which informed the U.S. Department of Energy about the incident. The official said: "This incident is tied to a broader issue. There are a couple of other occasions when the Chechens may have acquired nuclear or radioactive sources. Russia is rightly very concerned about that." The IAEA, Russia's Ministry of Atomic Energy, and the Volgodonskaya nuclear power station, deny the Rostov theft took place. An IAEA spokeswoman said their code of conduct would not oblige them to treat such an incident in confidence. Nick Paton Walsh, "Russian Nuclear Theft Alarms US," The Guardian, July 19, 2002. 
Russia out of Chechnya and enable the separatists to establish an independent state as long as the attack was highly publicized and caused sufficient damage.

The first was a hostage-taking raid staged by Basayev in the southern Russian town of Budyonnovsk in June 1995, where more than 125 people were killed. The raid caught Russian lawenforcers off guard and culminated in the seizure of a maternity ward. Using hostages as human shields, the separatists slipped back into Chechnya unpunished. Following this raid the Russian government suspended its military campaign in Chechnya.

The second occurred in August 1996 when rebels infiltrated the Chechen capital of Grozny months after it had been conquered by Russian troops. Having covertly snuck into Grozny in small groups, they seized control of large parts of the city in a surprise attack, eventually forcing Moscow to negotiate the withdrawal of troops from Chechnya. The withdrawal led to the Khasavyurt Accords, which deferred determination of Chechnya's legal status, giving the republic de-facto independence.

Separatists' confidence that the seizure of Grozny or a conventional terrorist act could reverse the course of war in Chechnya faded away in October 2002 after the federal authorities refused to yield to demands of a group of Chechen terrorists who executed a hostage situation similar in scale to that in Budyonnovsk. The Movsar Barayev-led attack on a musical theater involving more than 700 hostages in southeast Moscow did not accomplish the terrorists' goals: The Kremlin refused to meet their demands even after the terrorists threatened to start killing the hostages. Instead, Russian commandoes stormed the theater on October 26. More than 120 hostages died, most of them succumbing to the effects of a gas that Russian law-enforcers used to sedate the hostage-takers. Soon after the attack Putin vowed "Russia will make no deals with terrorists and will not give in to any blackmail. ${ }^{64}$

${ }^{64}$ Oliver Bullough, "Putin Vows No Deal with “Terrorists” after Siege,” Reuters, October 28, 2002. 
Now that a conventional terrorist attack has failed to meet their political objectives, Chechnya-based radical separatists may see catastrophic nuclear terrorism as one of the few options that will force Russia into leaving Chechnya.

"We cannot guarantee that there will not be another group on Russian territory," Maskhadov's envoy Akhmed Zakayev said after the hostage-taking drama in Moscow ended. "Terrorist acts are possible. We cannot exclude that the next such group takes over some nuclear facility. The results may be catastrophic, not only for Russian society and for Chechen society but for the whole of Europe." ${ }^{65}$

Proof of motivation. There is much proof of Chechnya-based radical separatists' motivation to commit acts of catastrophic nuclear terrorism and engage in WMD coercion, and it ranges from a plan to hijack an atomic submarine to threats to attack Russia's NBC facilities.

Perhaps the most stunning instance of the possibility of a nuclear terrorism attack was revealed in January 2002 when federal troops found late Chechen president Dzhokhar Dudayev's personal archive in the village of Starye Atagi, which contained a detailed plan to hijack a Russian atomic submarine. Vladimir Moltenskoi, commander of the federal troops in Chechnya, told reporters a month later that the plan provided for seven Slav-looking fighters to seize a submarine from the Russian Navy's Pacific Fleet sometime in 1995-96, which would coerce Moscow into withdrawing troops from Chechnya and recognizing the republic as an independent state. Moltenskoi said detailed military maps of Primorskii Krai, where the Pacific Fleet has bases, were found along with the plan. According to an April 26, 2002 Russian television report, the plan

${ }^{65}$ Gleb Bryanski, “Denmark: Interview-Chechens Could Strike Nuclear Plant Next,” Reuters, October 27, 2002. 
specifically provided for taking a nuclear warhead from the hijacked submarine to Chechnya. ${ }^{66} \mathrm{~A}$ Chechnya-based correspondent of Russian State Television said the plan ended this way: "together with the hostage(s)... and the nuclear warhead they will leave for Chechnya in a plane." ${ }^{97}$

Former naval officer Islam Khasukhanov allegedly developed the plan back in 1995 and then-chief of the Chechen General Staff Maskhadov reviewed the plan and wrote notes on it, according to Moltenskoi. ${ }^{68}$ Dudayev's archive also contained plans to blow up installations at nuclear power stations, military airfields, and oil refineries. ${ }^{69}$

The command of the Pacific Fleet claimed that security at Russian military nuclear facilities was adequate and the planned hijacking would have failed. "This could happen only in a foreign fantasy-action movie. In reality, it is a doomed plan," a spokesman for the fleet said. ${ }^{70}$ Yet, two

${ }^{66}$ The Pacific Fleet presently operates no nuclear-powered ballistic missile submarines, but it still has some 20 nuclear powered submarines, including those of the Oscar-II class that can carry nuclear torpedoes, according to Norway's nuclear watchdog Bellona.

${ }^{67}$ RTR Television, April 26, 2002, transcribed by BBC Monitoring on April 26, 2002. No other media reported this information, however.

${ }^{68}$ Federal troops seized Khasukhanov during a raid in the Chechen town of Shali on April 21, 2002. Khasukhanov had served on Russian submarines before leaving the Pacific Fleet in the rank of naval commander to become chief of the operational department of the Chechen separatists' general staff. Upon arrest, Khasukhanov decided to cooperate with federal troops and even revealed locations of the separatists' bases. Nothing has been reported either about Khasukhanov's whereabouts or what other information he has provided to Russian authorities since April 28, 2002. "Nachalnik Operativnogo Shtaba Maskhadova Gotovil Plan Zakhvata Rossiiskoi Atomnoi Podlodki (Chief of Maskhadov's Operational Staff Was Preparing a Plan to Hijack Russian Atomic Submarine," RIA-Novosti, April 25, 2002. 69 "V Chechne Nashli Plan Zakhvata Rossiiskoi Lodki (Plan to Hijack a Russian Submarine Found in Chechnya,)" Lenta.ru, February 4, 2002, available at www.lenta.ru/vojna in Russia as of July 4, 2002.

Also reported in "Nachalnik Operativnogo Shtaba Maskhadova Gotovil Plan Zakhvata Rosiiskoi Atomnoi Podlodki (Chief of Maskhadov's Operational Staff Was Preparing a Plan to Hijack Russian Atomic Submarine," RLA-Novosti, April $25,2002$.

70 "Komandovanie TOF: Chechenskim Boevikam Ne Pod Silu Zakhvatit Podlodku (Command of the Pacific Fleet: Chechen Rebels Are Incapable of Hijacking A Submarine,)” RIA-Novosti, February 5, 2002, available at http://www.lenta.ru/voina/2002/02/05/submarine/ as of June 28, 2002. 
years after Khasukhanov's plan was supposed to have been implemented, a single sailor managed to take hostages and lock himself up in a Russian nuclear submarine.

Other proof of Chechnya-based radical separatists' willingness to engage in WMD blackmail, if not acts of catastrophic nuclear terrorism, includes:

- In 1992, Dudayev warned the Kremlin that his fighters may attack nuclear plants in Russia in an effort to discourage Moscow from trying to counter his republic's independence bid. Dudayev was the first prominent Chechen separatist to publicly make such a threat. He repeated it in 1995 during military campaign. ${ }^{71}$

- In 2001, "suspicious persons" scouted Russian nuclear arsenals in May and July. They were detained, according to a Russian newspaper, and confessed to military counter-intelligence officers of the Federal Security Service that they were acting on orders of "Chechens" and they had been paid large sums of money to scout the facilities, according to Rossiiskaya Gazeta. $^{72}$

- In a separate 2001 case, two "reconnaissance and sabotage groups" of Chechen rebels "displayed interest" in how nuclear arms are transported across Russia. The groups were spotted at several key railway stations in the Moscow region, and according to the Gazeta, "They seemed to have been very interested in the special train, which is designed for shipping atomic bombs." ${ }^{, 73}$

- Also in 2001, General Igor Valynkin, head of the $12^{\text {th }}$ Main Directorate of the Defense Ministry, reported that terrorist groups made two attempts to probe security at the Russian

\footnotetext{
71 "Dudayev Grozit Perenesti Voinu v Glub' Rossii, (Dudayev Threatens to Transfer War Into the Depths of Russia,)" Vecherny Chelyabinsk, February 1, 1995.

72Vladimir Bogdanov, "Propusk K Boegolovkam Nashli U Terrorista, (A Pass To Warheads Found on a Terrorist,)" Rossiiskaya Gazeta, November 1, 2002.

${ }^{73}$ Ibid.
} 
Defense Ministry's nuclear facilities during that year. ${ }^{74}$ Both reconnaissance attempts were derailed, the general said. But he noted that it was possible that terrorists "may hatch some ground operations" against Russian nuclear arsenals. The general did not specify who probed security at the Defense Ministry's nuclear facilities, but it is unlikely that any terrorist groups other then the Chechnya-based radical separatists would be interested in this reconnaissance. $^{75}$

- In 2002, one group of Chechnya-based radical separatists cased Moscow's Kurchatov Institute, which houses several research reactors. The Barayev-led group (the same one that captured the Moscow theater in October) had planned to seize one of the Kurchatov Institute's reactors. ${ }^{76}$

- Most recently, Chief of Russia’s nuclear safety watchdog Gosatomnadzor Yuri Vishnevsky reported that Chechen rebels continue to target Russian nuclear facilities with nuclear power plants (NPPs) in southern Russia. "Now and then... Basayev and others declare that actions against nuclear facilities are inevitable. Both our information and information from power agencies indicate that such attempts occur," Vishnevsky said. He said he is especially concerned about the Rostovskaya and Novoronezhskaya NPPs in southern Russia. ${ }^{77}$

While less organized than their Chechnya-based counterparts, separatists in Dagestan and Karachayevo-Cherkessia are also motivated to push Russia out of the region as they seek to establish

\footnotetext{
${ }^{74}$ Mikhail Khodaryonok and Vladimir Georgiev, “Terroristy Podbirayutsya k Yadernym Arsenalam, (Terrorists Are Making Their Way To Nuclear Arsenals,)"Nezavisimaya Gazeta, October 27, 2001 available at http://www.ng.ru/world/2001-10-27/1_arsenal.html as of July 4, 2002.

75 Ibid.

${ }^{76}$ Bogdanov.

77 Press conference of chief of Russia's nuclear safety watchdog Gosatomnadzor Yuri Vishnevsky in Moscow, February 21, 2003, attended by the author.
} 
an independent Islamist state in the North Caucasus. Dagestani Islamist separatists even managed to establish an independent "Islamist territory" in Dagestan's Buinaksk district in $1998 .^{78}$ Russia's domestic security and law-enforcement blame Chechen-trained militant salafites from Dagestan and Karachayevo-Cherkessia for staging a series of terrorist acts outside Chechnya, including the destruction of a Buinaksk apartment building in $1999 .^{79}$ If a terrorist can blow up an entire apartment building, he may also assist Chechnya-based radical separatists in detonating a radioactive bomb that would cause comparable immediate casualties.

In addition to their specific political goals, the emotional motivation for Chechnya-based radical separatists to stage terrorist attacks in the North Caucasus and elsewhere in Russia has significantly increased during Russia's two military campaigns in Chechnya. Blood vendetta has

\footnotetext{
${ }^{78}$ The local salafites declared "Islamist territory ruled by the Sharia law" in four settlements of Dagestan's Buinaksk district, known as the Kadar zone, in 1998. Russian troops managed to overtake the villages in August 1999. Vladimir Bobrovnikov, "Islam in the Post-Soviet Northern Caucasus (Dagestan): Myths and Reality," Islam in the Post-Soviet Newly Independent States: The View from Within, edited by Alexei Malashenko and Martha Brill Olcott, Moscow Carnegie Center, Moscow, July 2001.

${ }^{79}$ Russian court sentenced natives of Dagestan Isa Zainudinov and Alisultan Salikhov to life in prison for involvement in the organization of a deadly apartment bombing in the Dagestani city of Buinaksk. Russian prosecutors insisted that it was Chechnya-based warlord Khattab who ordered the blast that killed 62 when a powerful bomb went off in front of a 50-apartment building in Buinaksk on September 4, 1999. Simon Saradzhyan, "After One Year, Blast Probe Still Drags On," The Moscow Times, September 15, 2000. Russian law-enforcers also maintain that Khattab ordered the bombings of apartment buildings killing some 220 people in Russian cities during fall 1999. One of the alleged bombers and native of Karachayevo-Cherkessia Adam Dekkushe was arrested in 2002 and told investigators of the Federal Security Service (FSB) that it was this salafite-minded warlord who issued the order through his subordinate Sheikh Abu Omar, deputy chief of FSB Operations and Search Directorate Yevgeny Kolesnikov told reporters in Moscow on July 17, 2002. RTR Television, July 17, 2002. Dekkushev also told investigators that the alleged terrorists had initially planned to bomb a dike in southern Russia to flood several settlements in hopes of killing thousands, but then changed their minds. Alexander Shvarev, "Zrya My S Rebyatiami Etim Zanimalis" [We should not have been doing this with guys], Vremya Novostei, February 19, 2003. According to Alexander Litvinenko, former Lt. Colonel of FSB, however, it could have been the FSB that organized the apartment bombings. Litvinenko, who claims to have spoken to Gochiyaev, has not backed his allegations with any direct evidence, however. Yuri Felshitinskii and Alexander Litvinenko, "Blowing
} 
been a cultural element ingrained in the North Caucasus for centuries, and the ongoing warfare and civilian casualties have made separatists highly vengeful. Some Chechen separatists have had relatives and brothers-in-arms killed by Russian troops, who have at times resorted to indiscriminate fire and have been accused of kidnapping and torturing civilians. Since separatists often cannot identity those specifically guilty of abuse (Russian troops often wear masks during raids and do not always identify themselves) they target any Russian personnel or facility in their quest for revenge.

\section{Possible Scenarios of Nuclear Terrorist Attacks}

Since Chechnya-based radical separatists are both capable and motivated to attempt acts of catastrophic nuclear terrorism, it is feasible that they could take advantages of flaws in the existing system of nuclear security in order to do so. They could hire intermediaries from an organized crime group who would either bribe or coerce personnel at a nuclear facility to steal weapons grade material or spent nuclear fuel. They could also attempt to steal nuclear materials during transportation, as there have been cases where materials disappeared during preparation for shipment or transit. ${ }^{80}$ In other cases, containers transporting nuclear materials were damaged, thus theoretically making unauthorized access easier. ${ }^{81}$

Up Russia: Terror From Within," Liberty Publishing House, New York, United States, 2001, fragments from the book are available at http://2001.NovayaGazeta.Ru/nomer/2001/61n/n61n-s00.shtml as of June 12, 2002.

803.6 kilograms of heat-emitting elements were missing upon arrival at the Siberian Chemical Combine plant in Seversk from the Novosibirsk Chemical Concentrates Plant sometime in 2000-2001. Vladimir Kuznetsov, "Nuclear Danger. Main Problems and Present Condition of Security at Enterprises of Nuclear Fuel Cycle of the Russian Federation,” Epicenter, Russia, 2003. Also some of the spent nuclear fuel shipped to the Mayak Production Association in the Chelyabinsk region could have disappeared in May 2001. Some of the heat emitting assemblies, which were shipped from a facility designed to accumulate spent nuclear fuel from submarines by train, had only half of the spent fuel they were supposed to carry upon their arrival at Mayak. Investigators failed to find the missing fuel and had to conclude that the fuel disappeared at the spent fuel facility. Letter by director general of Gosatomnadzor Yuri Vishnevsky to deputy prime minister Ilya Klebanov, November, 22, 2001, available at the web site of the Citizens' Center on Nuclear NonProliferation: http://nuclearno.ru/text.asp?1302 as of February 9, 2003. 
Even though Chechnya-based radical separatists are not known to possess the expertise to build an atomic bomb with stolen weapons grade material, they still can pack the spent fuel with explosives and then use several containers to deploy it in Moscow or another major Russian city. They would then detonate one of the containers in a crowded location and again try to put pressure on the Russian leadership. A dirty bomb made with fifty kilograms of nuclear power plant spent fuel packed around forty-five kilograms of conventional explosives could kill hundreds, if not thousands, with many of the deaths occurring weeks and months later, when exposure to radiation takes its toll. ${ }^{82}$ An attack like this would also cause nationwide panic and generate more publicity, for instance, than bombing an airliner.

Another variant could be that radical separatists would try to sabotage a nuclear facility, such as a NPP or research reactor. They might penetrate a facility with agents placed as insiders, take hostages, plant explosives at a storage facility for nuclear materials, a reactor, or even a nuclear arsenal, and use this attack to coerce the Russian leadership into pulling troops out of Chechnya. Extrapolating from the Chernobyl accident, immediate casualties of this type of terrorist attack could number in dozens or hundreds. In addition, an explosion of a nuclear reactor would have long-term effects on the health of thousands, if not tens of thousands of people, especially since four million people reside within 30-km zones around Russian NPPs and in the immediate vicinity of other nuclear fuel facilities, according to former inspector at Gosatomnadzor Vladimir

\footnotetext{
${ }^{81}$ According to Vladimir Kuznetsov, former chief inspector of Russia’s Gosatomnadzor, there have been several cases since 1996 of containers with nuclear materials being damaged during rail transportation. For a complete list see, Vladimir Kuznetsov, "Nuclear Danger. Main Problems and Present Condition of Security at Enterprises of Nuclear Fuel Cycle of the Russian Federation,” Epicenter, Russia, 2003.

${ }^{82}$ James Kitfield, “Threat Assessment: Could Terrorism Go Nuclear?” National Journal, 19 December 2001.
} 
Kuznetsov. ${ }^{83}$ This type of explosion would have a psychological impact similar to that caused by a dirty bomb attack. ${ }^{84}$

It is important to bear in mind that sabotaging modern nuclear reactors, which have a redundancy of vital safety functions, would require profound knowledge of their design, including awareness of which NPP-specific equipment would need to be destroyed to cause a reactor meltdown and where the equipment is located. ${ }^{85}$ There is no firm evidence that Chechnya-based radical separatists have this knowledge, although the October 2002 arrest of one of the Kalininskaya NPPs suggests they are trying to obtain it.

In a worst-case scenario, Chechnya-based radical separatists can use the same technique to attempt a hijacking of a submarine equipped with nuclear warheads or seize atomic demolition munitions en route to a facility, attempting to compel the Kremlin to pull troops out of Chechnya or recognize the republic's independence. An explosion of a nuclear warhead in a city would immediately kill hundreds of thousands and would send panic waves across the entire continent. ${ }^{86}$ This variant is least probable, however, as nuclear weapons are accorded the highest security. Additionally, defense, security, and law-enforcement agencies usually screen candidates and check their background before clearing them to guard such facilities as NPPs, research reactors, and nuclear arsenals.

\section{The Challenge of Discerning Messianic Terrorist Threats}

\footnotetext{
${ }^{83}$ Kuznetsov.

84 Pikayev Interview.

85 Oleg Bukharin, "Upgrading Security At Nuclear Power Plants In The Newly Independent States," The Nonproliferation Review, Center for Energy and Environmental Studies, Princeton University, United States, 1997. 86 An explosion of a 25-megaton nuclear warhead over the heart of Detroit or St. Petersburg, for instance, would kill immediately anywhere between 200,000 and 2,000,000, according to “The Effects of Nuclear War," Office of Technology Assessment, Congress of the United States, May 1979.
} 
Even careful screening might fail to weed out members of a messianic sect who remain silent about their beliefs, secretly committed to fulfill the orders of their leaders. There is no publicly available evidence that any of the Chechnya-based radical separatist groups have messianic ambitions although some of their leaders have maintained contacts with al-Qaeda and repeatedly referred to the Koran when trying to justify the use of violence in their secessionist bid. ${ }^{87}$ There has been at least one case, however, where a messianic cult that has attempted to stage acts of WMD terrorism recruited hundreds of followers across Russia into its ranks, including employees of Russia's premier nuclear research facility. This cult was Aum Shinrikyo, which dispersed anthrax spores in the Japanese capital in 1993 and sprayed sarin in the Tokyo subway in 1995. The cult's leader, Shoko Asahara, ordered the attacks in an effort to provoke a war between Japan and the United States in November 1995. He believed that a U.S.-Japanese war would lead to complete

\footnotetext{
${ }^{87}$ There have been numerous reports about links between Chechen separatists and al-Qaeda. Some noteworthy examples include: (1) U.S. charge d'affaires in Tbilisi Philip Remler suggested in February of 2002 that the Chechen contingent in Georgia's Pankisi gorge could include individuals with ties to al-Qaeda, "Georgian Defense Minister Doubts Al-Qaida In Pankisi," RFE/RL, May 10, 2002, available at http://www.rferl.org/newsline/2002/05/2-
} TCA/tca-100502.asp as of July 14, 2002.

(2) U.S. intelligence agencies have estimated that as many as 100 al-Qaeda militants joined hundreds of Chechen fighters who set up base in Georgia’s troubled Pankisi gorge. Peter Baker, “Arab Militants Turned Over to U.S. by Georgian Forces," The Washington Post, October 21, 2002. (3) The FBI also believes there are ties between Chechen separatists and al-Qaeda. "Although al-Qaeda functions independently of other terrorist organizations, it also functions through some of the terrorist organizations that operate under its umbrella or with its support, including: the Al-Jihad... and the Chechen region of Russia.” J. T. Caruso, Acting Assistant Director, Counter Terrorism Division, Federal Bureau of Investigation, Statement for the Record on Al-Qaeda International Before the Subcommittee on International Operations and Terrorism Committee on Foreign Relations, United States Senate, Washington, D.C., December 18, 2001, available at http://www.fbi.gov/congress/congress01/caruso121801.htm as of July 14, 2002. (4) There have been reports about Chechens fighting on the al-Qaeda side in Afghanistan. Two Chechen members of al-Qaeda were killed in a gun-battle with Pakistani troops in Azam Warsak, a remote tribal area of Pakistan bordering Afghanistan on June 26, 2002, unidentified Pakistani officials said. The same area saw Pakistani security officials capture a Chechen, identified as Muhammad Yahya, also in June, the officials said. M. Ismail Khan, "10 Soldiers, Two Fugitives Killed: Al-Qaeda Hideout In Tribal Area Raided," Dawn, June 27, 2002. 
destruction of his country, and the Aum cult would then be able to revive a Japanese nation spoiled by internationalism and materialism. ${ }^{88}$

A report from the Russian State Duma's Security Committee put the number of Aum's Russian followers at 35,000, with up to 55,000 more people visiting the sect's seminars sporadically. ${ }^{89}$ The Duma committee reported that the Russian sect had 5,500 full-time monks who lived in Aum accommodations. The Aum began its activities in Russia in 1991 and the Russian branch quickly grew to become this messianic cult's largest organization in the world, according to an October 1995 statement by the staff of the U.S. Senate Government Affairs Permanent Subcommittee on Investigations. In addition to recruiting thousands of Russians into the cult's rank-and-file, the cult has also established contacts within Russia's ruling elite. Asahara led a delegation of 300 Aum members to Russia in March 1992 to meet with then-Vice President Aleksandr Rutskoi and Russian parliament speaker Ruslan Khasbulatov. There were also allegations printed in the Russian press that then- Secretary of the Russian Security Council, Oleg Lobov, received hefty bribes from Aum. The Russian State Duma’s Security Committee reported that Aum had at least seven branches inside of Moscow, and eleven headquarters outside Moscow, including in St. Petersburg, Kazan, Perm, Vorkuta, Tyumen, Samara, Vladivostok, Elista, and Vladikavkaz. ${ }^{90}$

In addition to recruiting followers, the cult also sought to acquire various weapons in Russia. ${ }^{91}$ For instance, questions regarding the cost of nuclear weapons are posed in documents seized from the Aum's construction minister Kiyohide Hakawa. ${ }^{92}$

\footnotetext{
${ }^{88}$ Staff of the Senate Government Affairs Permanent Subcommittee on Investigations, "Global Proliferation of Weapons of Mass Destruction: A Case Study on the Aum Shinrikyo," October 31, 1995, available at http://www.fas.org/irp/congress/1995_rpt/aum/part06.htm as of July 31, 2002.

${ }^{89}$ Ibid.

${ }^{90}$ Ibid.

${ }^{91}$ Ibid.

92 Ibid.
} 
The cult actively recruited scientists and technical experts in Russia, as well as in other countries, in order to develop weapons of mass destruction. Aum allegedly managed to recruit followers even at the Kurchatov Institute, which had Aum followers as employees, according to the U.S. Senate statement. ${ }^{93}$

The fact that Aum managed to recruit thousands of followers and operate across Russia proves that messianic cults and groups - including al-Qaeda cells, whose leaders strive for catastrophic terrorism — can operate below the radar of Russian law-enforcers. Just as police and secret service failed to identify what Aum's real intentions were until the 1995 subway attack, it may prove difficult for Russian law-enforcement and security agencies to discern which of the cults currently operating in Russia may have similar messianic terrorism ambitions before they strike. It may also be extremely difficult to locate and neutralize all branches of a messianic terrorist organization even after it strikes, as is the case with al-Qaeda cells in North America. ${ }^{94}$

However, neither followers of messianic cults nor Chechnya-based radical separatists would need to attack a Russian nuclear facility in order to obtain nuclear materials. As further sections of this paper will demonstrate, corrupt employees and gangsters can and have already stolen and sold nuclear materials to customers inside Russia and abroad.

\section{Criminals Take Advantage of Insufficient Security at Nuclear Materials Facilities}

The Russian government has failed to ensure adequate security at many civil nuclear facilities. A sizeable portion of Russia's atomic industry enterprises handling nuclear materials still

\footnotetext{
93 Ibid.

94 U.S. law-enforcement agencies have been combing America for these cells while trying to build a firewall along the borders since September 11, 2001. Yet, the FBI has to regularly issue terrorism alerts, including warnings of possible attacks on nuclear facilities.
} 
do not comply with Material Protection, Control, and Accounting (MPC\&A) standards. ${ }^{95}$ Also, none of the units guarding Russia's civil nuclear facilities are armed with air defense systems capable of shooting down kamikaze pilots. ${ }^{96}$ As a result, thefts have occurred at Russia's nuclear facilities, including NPPs. Some of the thefts occurred because nuclear materials were not adequately secured as guards either left their posts or refused to patrol perimeters. ${ }^{97}$

Fortunately, no allegations of nuclear weapons thefts in Russia and other former Soviet republics have proven to be true. However, absence of such thefts does not mean that security is

\footnotetext{
95 By February 2001, MPC\&A upgrades had been completed only at 81 out of 251 Russian military and civil nuclear sites designated by U.S. Department of Energy as in need for such upgrades. Rapid upgrades had been completed at another 34 facilities, work had begun at another 69 facilities, while work was yet to begin at 69 facilities, according to U.S.
} General Accounting Office’s 2001 report, “Nuclear Nonproliferation: Security of Russia’s Nuclear Material Improving; Further Enhancements Needed,” Report to Congressional Requesters, U.S. General Accounting Office, February 2001. The number of enterprises where the upgrades have been completed could not have increased dramatically since then, according to Alexander Pikayev, interview by author, January 2003.

According to a book written by Vladimir Kuznetsov, former inspector at the Gosatomnadzor nuclear security watchdog, most Russian facilities, which house nuclear reactors, lack equipment to detect unauthorized removal of nuclear materials or explosives brought onto the ground of a facility. Most of these facilities also lack optical-electronic equipment to monitor security perimeters and have no barriers at checkpoints to prevent vehicles from crashing through onto the territory, according to the book. A significant number of facilities lack security services while some of those guarded by security services lease space to commercial companies. Kuznetsov.

96 The Russian government is still only planning to arm units guarding Russian nuclear facilities with air defense systems, according to Yuri Vishnevsky, chief of Russia’s nuclear security watchdog Gosatomnadzor. The government and parliament need to amend the existing laws to allow for shooting down of aircraft flying over nuclear facilities before these air defense systems can be actually used, the official said. "There should be a precise provision that would require any intruder to be shot down. It is not important who the intruder is as it can be sorted out later," the official said.

"Vtorgsya-Sbivat" [Intruders must be shot down], Gazeta, November 26, 2002.

${ }^{97}$ At some nuclear facilities, guards of the Interior Ministry's Interior Troops have left their posts to forage for food. Others have been reluctant to patrol facility perimeters because they did not have winter uniforms to keep them warm on patrol. In some instances, recently installed security equipment is not being used because there is no money to maintain it; at others facilities, guards who had not been paid in months were expected to man unheated posts in subfreezing conditions. "Prospects for U.S.-Russian Cooperation for Nonproliferation in the Post-Cold War Era," William C. Potter, presentation to the Defense and Security Committee of the North Atlantic Assembly, 44th Annual Session, Edinburgh, November 10-13, 1998. 
sufficiently robust at all of Russia's military nuclear facilities. The July 1993 theft of HEU from a naval base and the October 1998 hostage-taking incident with Dagestani guards at a Northern Fleet nuclear facility demonstrated that security at these facilities could be breached. ${ }^{98}$

Perhaps the most dangerous incident occurred in the Northern Fleet in September 1998 when nineteen-year old sailor Alexander Kuzminykh locked himself in one of the fleet's nuclearpowered submarines, threatening to blow it up. The sailor killed six fellow servicemen before locking himself and two hostages inside the Akula-class hunter-killer submarine, which was docked at the fleet's Skalisty base near Murmansk. Kuzminykh subsequently shot both hostages dead and repeatedly threatened to start a fire on board to detonate torpedoes inside the nuclear submarine. Responding to this threat, Northern Fleet spokesman Sergei Anufriyev said the submarine's nuclear reactor was shut down and Kuzminykh could not have blown up or sunk the submarine. After hours of fruitless negotiations, the sailor shot himself. It was later revealed that the sailor might have been mentally disturbed. ${ }^{99}$

In May 2000, two cadets at a training center that drills guards for nuclear weapons facilities were expelled because they had each failed a drug test. During the same month, the Defense

\footnotetext{
98 Matthew Bunn, “The Next Wave: Urgently Needed New Steps to Control Warheads and Fissile Material,” Carnegie Endowment for International Peace and Project on Managing the Atom, Belfer Center for Science and International Affairs, John F. Kennedy School of Government, Harvard University, April 2000, available at http://bcsia.ksg.harvard.edu/publication.cfm?program=CORE\&ctype=book\&item_id=28 as of March 3, 2003. The two servicemen were sentenced to 5 years and 4 years, respectively, in November 1995. Mikhail Kulik and Vladimir Orlov, "Uranovaya Krazha: Istoriya Guby Andreeva" [Theft of uranium: history of Guba Andreeva], Moskovskiye Novosti, October 1995.

99 The fleet's spokesman Anufriyev said the submarine's automated fire-extinguishing systems would put out any flames set by Kuzminykh. He also said it would take an experienced officer to activate the submarine's torpedo detonators. Despite the spokesman's confidence, however, nearby warships and submarines were evacuated, as FSB commandos remained unable to get to Kuzminykh until he shot himself inside the submarine, where he had remained separated from the law-enforcers by a 10-cm-thick steel hatch. Simon Saradzhyan, "Sailor Kills Himself After Standoff in Sub," The
} 
Ministry began assigning officers instead of soldiers as guards for transporting nuclear warheads. This decision was made after it was discovered that guards deserted their posts in seven instances during the course of one month, clearly demonstrating that the conscript problem has had an influence on the military's assignment policy. ${ }^{100}$

Draft-dodging and legal exemptions from conscription have forced the Defense Ministry and other Russian agencies to enlist even those with psychiatric problems, histories of drug abuse, and criminal convictions, ${ }^{101}$ in spite of the fact that in several cases, armed soldiers have fled their units, shot fellow servicemen, and taken hostages. ${ }^{102}$ Most recently a soldier manning a hardware storage site of the Strategic Rocket Forces in Siberia killed four servicemen in February 2003. Private Sergei Khasanov sprayed his comrades with automatic fire in the guardroom of his unit located in the Krasnoyarsk region, and then shot himself. A spokesman for the force said the Moscow Times, September 15, 1998, available at http://www.themoscowtimes.com/stories/1998/09/15/015.html as of July 14, 2002.

100 Maxim Kniazkov, “US Certifies Theft of Russian Nuclear Material Has Occurred,” AFP, February 23, 2002. 101 As many as 30,000 dodged draft in spring 2002, according to General Vasily Smirnov, acting chief of the General Staff of the Russian Armed Forces' Main Directorate for Mobilization. Smirnov warned that Russian armed forces could suffer from a 50 percent lack of rank-and-file personnel in 2012 because of the continuing depopulation. Seven percent of conscripts serving in the Russian armed forces as of spring 2002 had convictions before being recruited. "Vesenni Prizyv V Armiy Zavershen" [Spring conscription to the army is completed], Lenta.ru, July 10, 2002, available at http://www.lenta.ru/russia/2002/07/10/prizyv/ as of July 14, 2002.

102 The following accidents occurred in just five days in June 2002: On June 11 a soldier shot two fellow servicemen in Chechnya and fled. The deserter subsequently shot himself when surrounded by law-enforcers. On June 14, soldiers hijacked an armored personnel carrier in Khabarovskii Krai and crashed it into a cafe to get vodka and food. They then hijacked an army truck to get back to the unit upon fracturing the skull of the truck's driver. On June 15 two armed guards fled from the Maikop Infantry Brigade in the Republic of Adygea, southern Russia. The pair hijacked a car and killed two policemen who tried to stop them. "Nesmotrya Na Ezhdenevnye ChP, v Minoborony Utverzdhayut Chto Prestupnost Snizhaetsya" [Despite daily incidents, the ministry of defense claims that crime is falling], Lenta.ru, June 16, 2002, available at http://lenta.ru/russia/2002/06/16/army/ as of July 14, 2002. 
soldier had been suffering a nervous breakdown. ${ }^{103}$ This type of scenario clearly could have drastic security consequences regardless of its cause.

\section{Capability to steal}

Inadequate security increases opportunities for those conspiring to steal nuclear materials. Even the best-developed security system of Russia's nuclear arsenal is stressed by lack of funds and vulnerable to insider threat, according to the U.S. National Intelligence Council. ${ }^{104}$ Many of the measures taken by Russian authorities to secure nuclear weapons are not designed to counter threats that could be posed by insiders - those who know the most about a facility's vulnerabilities - who may attempt unauthorized actions. ${ }^{105}$

Several authoritative reports, including the U.S. Department of Energy's Baker-Cutler report, have documented cases when those with official access to such facilities have either stolen or helped steal nuclear materials in Russia. ${ }^{106}$ In one instance, employees of a civil nuclear facility in the Chelyabinsk region conspired to steal 18.5 kilograms of weapons-usable material, but were thwarted by Federal Security Service agents. ${ }^{107}$ To date, this has been the only publicly known case involving enough material for an entire nuclear bomb. ${ }^{108}$

103 “Guarsdman Could Have Shot Fellow Servicemen Near Krasnoyarsk Because of a Nervous Breakdown,” Interfax, February 20, 2003.

104 “Annual Report to Congress on the Safety and Security of Russian Nuclear Facilities and Military Forces," National Intelligence Council, February 2002.

105 Ibid.

106“A Report Card on the Department of Energy's Nonproliferation Programs with Russia," the Secretary of Energy Advisory Board, the United States Department of Energy, January 10, 2001, available 2002 at http://www.hr.doe.gov/seab/rusrpt.pdf) as of May 14, 2002.

${ }^{107}$ Major General Valery Tretyakov, head of the Chelyabinsk Oblast Federal Security Service (FSB), revealed on December 18, 1998, that FSB agents had thwarted a conspiracy by employees at a major nuclear facility in the Chelyabinsk region to steal 18.5 kilograms of weapons-usable nuclear material. The theft attempt, and the fact that if successful it could have caused "significant damage to the [Russian] state" was later confirmed by the Ministry of Atomic 
However, Russian law enforcers could not prevent all threats as security was so insufficient at some nuclear facilities that there was a time when stealing HEU was easier than taking potatoes, according to the Russian military investigator who probed Navy officer Alexei Tikhomirov's HEU theft in November 1993. ${ }^{109}$ Tikhomirov stole 4.5 kilograms of nuclear fuel rods enriched to over 19 percent U-235 from the Sevmorput naval shipyard near Murmansk, hoping to sell it for $\$ 50,000$ to international weapons dealers. ${ }^{110}$ His theft was possible because of holes in the shipyard's fences and a broken alarm connecting the guard post to the storage building at the Sevmorput facility.

The following are other cases involving the theft of weapons-usable nuclear materials in Russia:

- In late May and early September 1992, a chemical engineer and long-time employee of the Luch Scientific Production Association in Podolsk stole approximately $1.5 \mathrm{~kg}$ of weaponsgrade uranium. ${ }^{111}$

- In July 1993, 1.8 kilograms of 36 percent enriched HEU were stolen by two naval

Energy's head of nuclear material accounting. Yevgeny Tkachenko, "FSB Agents Prevent Theft of Nuclear Materials," ITAR-TASS, December 18, 1998; and "Interview: Victor Yerastov: MINATOM Has All Conditions for Providing Safety and Security of Nuclear Material," Yaderny Kontrol Digest, Vol. 5, No. 1, Winter 2000.

${ }^{108}$ Bunn.

${ }^{109}$ Oleg Bukharin and William Potter, "Potatoes Were Guarded Better," Bulletin of the Atomic Scientists, May- June 1995 , available at http://www.nti.org/db/nistraff/1995/19950880.htm as of June 28, 2002.

110 Bunn.

111 William Potter, Director of the Center for Nonproliferation Studies, Monterey Institute of International Studies, Oral Presentation Before the Permanent Subcommittee on Investigations, U.S. Senate Committee on Governmental Affairs, March 5, 1996, available at http://cns.miis.edu/pubs/reports/senoral.htm as of June 17, 2002. Confirmed in "Annual Report to Congress on the Safety and Security of Russian Nuclear Facilities and Military Forces," National Intelligence Council, February 2002.Russia's then deputy atomic energy minister Lev Ryabev confirmed this theft in an interview with Interfax in June 1994. He noted, however, that the stolen quantity was not enough to manufacture a bomb." Atomic Energy Minister: West Trying To Discredit Russia," Interfax, June 17, 1994, quoted in “Western Press Exaggerates Russian Nuclear Smuggling Threat Says Russia’s Deputy Minister for Atomic Energy, Lev Ryabev,” NIS 
servicemen from the Andreeva Guba naval base near Russia’s Norwegian border. ${ }^{12}$

- In August 1994, more than 360 grams of plutonium were seized in Munich on a plane from Moscow as a result of a German sting operation. ${ }^{113}$

- In 1994, three kilograms of 90 percent weapons-grade uranium were seized by Russian lawenforcers in St. Petersburg. ${ }^{114}$

- In December 1994, 2.73 kilograms of essentially weapons-grade uranium (87.7 percent U235) were seized in Prague. ${ }^{115}$

The following are some of the most recent cases involving the theft of non-weapons-grade nuclear materials in Russia:

- In May 1999, four residents of Russia were arrested in Ukraine while trying to smuggle 24 kilograms of enriched uranium ore from Krasnoyarsk Krai to Western Europe. ${ }^{116}$

Nuclear Trafficking Database, Center for Nonproliferation Studies, Monterey Institute of International Studies Nuclear Threat Initiative, available at http://www.nti.org/db/nistraff/1994/19940620.htm as of October 15, 2002.

112 Bunn. The two servicemen were sentenced to 5 years and 4 years, respectively, in November 1995. Mikhail Kulik and Vladimir Orlov, "Uranovaya Krazha: Istoriya Guby Andreeva," [Theft of uranium: history of Guba Andreeva], Moskovskiye Novosti, October 1995.

${ }^{113}$ Bunn.

${ }^{114}$ Russia's then Federal Counter-Intelligence Officers arrested three suspects attempting to sell about three $\mathrm{kg}$ of 90 percent enriched HEU, according to a report by the Monterey Institute of International Studies. The report said this case reported to the International Atomic Energy Agency by the Russian Federation. "Confirmed Proliferation-Significant Incidents of Fissile Material Trafficking in the Newly Independent States (NIS), "Center for Nonproliferation Studies, Monterey Institute of International Studies, 2002. According to a report in The Moscow Times, however, only two kilograms were seized. The paper quoted federal authorities as saying that an employee at a secret plant producing fuel for nuclear reactors near Elektrostal in the Moscow region stole the uranium from his plant in the spring of 1992. "Petersburg Arrests 3 for Trying to Sell Uranium,” The Moscow Times, June 09, 1994.

115 Bunn.

${ }_{116}$ Oleksandr Ilchenko, "Uranium From Krasnoyarsk Found in Transcarpathian Oblast,” Segodnya (Kiev), May 21, 1999, quoted in "Ukrainian Authorities Arrest Four Armenians Selling Russian Uranium," NIS Nuclear Trafficking Database, 
- In September 1999, police in Vladivostok arrested six men who tried to sell at least 3.5 kilograms of uranium-238. ${ }^{117}$

- In July 2001, officers of the Federal Security Service (FSB) arrested two residents of North Ossetia and one Azerbaijani citizen for illegal possession of 1.5 kilograms of uranium. One of the North Ossetians served as a colonel in the Interior Ministry when he bought the uranium in 2000 in an attempt to sell it to a buyer in Turkey. ${ }^{118}$

- In June 2002, police seized two kilograms of uranium from a Russian citizen in the city of Izhevsk, Russia. ${ }^{119}$

There have also been media reports of nuclear warheads stolen or missing in the former Soviet Union. Some attributed claims of "broken arrows" to officials, including then-secretary of Russia's Security Council Alexander Lebed and Ukrainian legislator Pyotr Simonenko. ${ }^{120}$ None of the alleged

Center for Nonproliferation Studies, Monterey Institute of International Studies Nuclear Threat Initiative, available at http://www.nti.org/db/nistraff/1999/19990460.htm as of July 4, 2002.

117 Georgii Kulakov, "Prodavtsy Urana Prinyali Militsionerov Za Banditov" [Uranium peddlers thought policemen were bandits], Kommersant Daily, September 2, 1999.

118 “Uranium Traffickers Convicted North Ossetia, Russia," NIS Nuclear Trafficking Database, Center for Nonproliferation Studies, Monterey Institute of International Studies Nuclear Threat Initiative, February 27, 2001, available at http://www.nti.org/db/nistraff/2001/20010130.htm as of July 4, 2002.

119 "Izhevsk, V Tsentre Goroda Izyato Dva Kilogramma Urana” [Izhevsk: two kilograms of uranium seized downtown], Kupol-Media, June 13, 2002. Also reported in "Prosecution Investigates the Case of 2 Kilos of Uranium Seized in Udmurtia," Nuclear.ru, June 10, 2002.

${ }^{120}$ Lebed stirred controversy in both Russia and the United States in May 1997 with his allegations that the Russian government is currently unable to account for some eighty small atomic demolition munitions (ADM's) which were manufactured in the USSR during the Cold War. Scott Parrish, "Are Suitcase Nukes on the Loose? The Story Behind the Controversy," Monterey Institute of International Studies, November 1997. Simonenko, who heads the Ukrainian parliament's Communist faction, told reporters in Kharkiv, Ukraine, on September 11, 2002 that transfer of only 2,200 out of 2,400 warheads, which Ukraine had on its territory at the time of disintegration of Soviet Union, have been documented, "The fate of the other 200 warheads is unknown," Simonenko said. He said that a special parliamentary 
thefts of nuclear warheads have been confirmed either by governments of former Soviet states or by the International Atomic Energy Agency (IAEA), however. While there is no evidence of nuclear weapons theft, it is well known that quite a few weapons were lost. In fact, more than forty Soviet nuclear weapons were lost in 1950-1993, according to renowned nuclear safety scholar Joshua Handler of Stanford University and Greenpeace, when the atomic submarines carrying them sank. ${ }^{121}$

One of these ill-fated submarines, which still remains at the bottom of the sea, is the K-278 Komsomolets. This Soviet Mike class (Project 685) nuclear-powered attack submarine sank off northern Norway following on-board fires and explosions on April 7, 1989. The submarine was powered by one nuclear reactor and carried two nuclear torpedoes. ${ }^{122}$

"Terrorists would need a few hours to take one warhead, about one day...to take the second one," one expert said, referring to the Komsomolets. ${ }^{123}$ The expert didn't explain how the terrorists could access the submarine, which is at a depth of 1,685 meters in the Norwegian Sea.

\section{Motivation to steal and sell}

In spite of modest improvements in living standards across Russia, thousands of Defense Ministry and Interior Ministry servicemen and nuclear industry workers continue to subsist on meager wages. The government remains unable either to substantially boost defense spending or to

commission probed the transfer to find out that the warheads could be missing. "Leader of Ukrainian Communists Confirm That 200 Warheads Have Vanished From the Territory of the Country," September 12, 2002.

121 “Accidents Involving Nuclear Weapons in1950-1993,” Greenpeace, March 1996, available at http://archive.greenpeace.org/ comms/nukes/ctbt/read3.html as of June 29, 2002.

122 Ibid.

Also reported in "Nuclear Submarine Accidents," Bellona Foundation, 1996, available at

http://www.bellona.no/en/international/russia/navy/northern fleet/11084.html\#O1 as of June 29, 2002.

123 Moscow News Confidential, February 1995, quoted in Vladimir Orlov, "Preventing the Threat of Nuclear Terrorism: The Case of Russia," Disarmament Diplomacy, The Acronym Institute, United Kingdom, 1998, available at http://www.acronym.org.uk/dd/dd20/20terr.htm as of July 15, 2002. 
dramatically downsize the bloated military industrial complex still structured to meet the needs of a global superpower.

In one instance, the Defense Ministry even had to close a nuclear weapons storage site because of hunger strikes by the workers. ${ }^{124}$ Some insiders, such as Navy officer Tikhomirov, have attempted to "earn" thousands of dollars from one theft rather than subside on a monthly wage of $\$ 200$ or less. In 2002, more Russian military servicemen were convicted of theft and embezzlement than of any other crime. ${ }^{125}$ This is consistent with the findings in British nuclear security expert Gavin Cameron's November 2001 report, which concludes that the overwhelming motivation for most of the insider crimes was self-serving financial gains. ${ }^{126}$ In pursuit of these, some thieves are unaffected by the very real possibility that the weapons that they have stolen and sold may be used against them. For example, prosecutors revealed in June 2002 that servicemen of an infantry brigade based in the Dagestani town of Buinaksk had stolen and sold an infantry mine, which was then used to kill dozens during a military parade in another Dagestani city, Kaspiisk, where 170 were wounded and 43 killed, including at least 16 military servicemen. ${ }^{127}$

Six servicemen of the Buinaksk brigade, including two senior officers, were detained in connection with this alleged sale, Russia's deputy prosecutor general Vladimir Kolesnikov revealed

\footnotetext{
124 “Annual Report to Congress on the Safety and Security of Russian Nuclear Facilities and Military Forces," National Intelligence Council, February 2002.

125 Various embezzlements topped the list of crimes, which Russian military servicemen were convicted for in 2002 , according to Nikolai Petukhov, chairman of the Military Board of he Supreme Court of the Russian Federation. "More Military Servicemen Get Convicted of Embezzlement Than of Any Other Crime,” Interfax, February 9, 2003.

126 Gavin Cameron, “Nuclear Terrorism: Reactors \& Radiological Attacks After September 11,” Symposium on International Safeguards: Verification and Nuclear Material Security, Vienna, Austria, 29 October - 2 November 2001. 127 “Genprokuratura: Minu Dlya Terakta v Kaspiiske Prodali Voyennye Iz Buinakska” [General Prosecutor's Office: the mine for the terrorist act in Kaspiisk sold by the military from Buinaksk], Lenta.ru, June 24, 2002, available at http://lenta.ru/terror/2002/06/24/names/ as of July 4, 2002.
} 
in June 2002, and were still in custody as of December 2002. ${ }^{128}$ It remains unknown whether the detained servicemen knew the identity of their buyers. There should be no doubt, however, that at least the two senior officers knew that Dagestani and Chechen radical separatists had targeted Buinaksk itself in the past: Dagestani separatists blew up a Buinaksk apartment building where military servicemen and their families resided in September 1999, and Chechnya-based rebels once attacked the local brigade.

The sale of the infantry mine challenges the assumption that corrupt officers would not sell nuclear materials or nuclear arms if they suspected that the stolen materials could be used against their comrades.

\section{Organized Crime and the Coercion of Insiders}

Though they are provided with the best access to nuclear materials and weapons, Russian military servicemen and employees of civil defense facilities have rather limited capability to traffick the stolen materials and find potential buyers for commodities like HEU and plutonium. Organized crime groups are more capable of finding a buyer and smuggling the commodity to him. In fact, cooperation between insiders and outsiders poses the most serious type of insider threat, according to Gavin Cameron's 2001 report. This applies not only to the embezzlement of nuclear material, but also to violent threats against nuclear facilities, according to a RAND report on nuclear security challenges. ${ }^{129}$ As RAND argued in its 1990 report on insider crimes, in each case the threat posed by the external group is considerably increased if the group has reliable knowledge of the plant's

\footnotetext{
128 Ibid.

${ }^{129}$ Bruce Hoffman, Christina Meyer, Benjamin Schwarz, Jennifer Duncan, "Insider Crime: The Threat To Nuclear Facilities and Programs," RAND Corporation, Santa Monica, CA, February 1990, quoted in Gavin Cameron, "Nuclear

Terrorism: Reactors \& Radiological Attacks After September 11,” Symposium on International Safeguards: Verification and Nuclear Material Security, International Atomic Energy Agency, Vienna, Austria, 29 October - 2 November 2001.
} 
security arrangements, procedures, operations, physical layout, and the location of the material or vulnerable point in the facility. The most likely source for such information would be from someone who works at the site: an insider. ${ }^{130}$

\section{Capability}

Having established ties with organized criminal groups abroad, the Russian mafia may now be capable of shipping WMD materials across Russia and then smuggling them out as they routinely do with drugs. In the past, Russian organized criminal groups have shown the capability to develop efficient and covert schemes of embezzlement that included the intimidation of employees of wellguarded enterprises and elaborate cover-ups. In one such case reported by Russia's NTV channel in 2001, the embezzlement of gold continued from a smelter even as a special law-enforcement taskforce began investigating the company. The task force spent weeks trying to determine why the smelter's books showed that all gold was accounted for even though embezzlement continued, as

employees acted under threats from an organized crime group to doctor the books and smuggle out the gold.

It is possible that organized criminal groups could employ a similar technique to steal HEU (if they have not done so already) as many of Russia's atomic industry enterprises still do not comply with MPC\&A standards. After coercing or bribing employees of a nuclear facility to steal HEU, gangsters can then smuggle it out of Russia and sell it for a hefty sum. The buyer could be an Islamist terrorist group, which could then transfer the HEU across Russia's porous southern border to their comrades-in-arms in Chechnya.

\section{Motivation}

130 Ibid. 
As far as is known, most Russian gangsters have displayed no strong interest in NBC materials, even though they are often more difficult to detect than drugs at border crossings and offer potentially higher profit margins. According to Russian non-proliferation experts, Russia's largest organized crime gangs are not interested in NBC materials because they do not know any potential buyers, as most of their international contacts are organized crime groupings that focus on drug and human trafficking, as well as other typical criminal activities in Europe and America. ${ }^{131}$

More importantly, there did not seem to be much of a real demand for nuclear materials on the European black market in the early 1990s. For example, of the 276 nuclear-smuggling crimes recorded in Germany in 1992-1994, almost all were sting operations, including two of the three discoveries of weapons-grade material in summer $1994{ }^{132}$

Another factor is that law-enforcement agencies would certainly put forth a serious effort to bring any gangster caught in a theft of weapons-grade nuclear material to trial and dismantle the associated gang. Russian security and law-enforcement agencies whose agents have infiltrated many of these gangs would be unlikely to tolerate attempts to steal and sell NBC components even though they sometimes turn a blind eye on typical criminal activities reported by their informants. Such consequences, in addition to the knowledge that the sold materials could be fired back, should theoretically discourage Russian gangs from selling HEU directly to Chechnya-based terrorist groups.

There are some gangsters, however, who have refused to abide by the "rules of the game." These gangsters, commonly known in the Russian underworld as "frozen outs," may try to smuggle

\footnotetext{
131 Orlov Interview, April 2002.

132 "Nuclear Smuggling Arrests Exposed as Stings," The Moscow Times, August 20, 1994, available at http://www.themoscowtimes.com/stories/1994/08/20/018.html as of July 4, 2002.
} 
nuclear materials out of Russia and try to sell them, according to Vladimir Orlov, director of the PIR Center, Russia’s leading nuclear security think-tank. ${ }^{133}$

Additionally, some organized crime and terrorist gangs have already begun to merge in Russia, thus increasing the threat posed by gangster-terrorist cooperation to stage terrorist acts. "The trend of organized crime groups merging with terrorism and extremism oriented groups is gaining strength," head of the anti-organized crime directorate of the Interior Ministry Alexander Ovchinnikov said in November 2002. ${ }^{134}$

There have been several cases of alleged smuggling of nuclear materials by organized criminal groups in the former Soviet Union and East Europe. In one 1992 case, German police were reported to have arrested a Polish gang offering to sell a nuclear warhead from ex-Soviet stocks. ${ }^{135}$ In another 1992 case, the Finnish newspaper Iltableti said that Russian dealers recently offered its reporters bomb-grade plutonium, a sample of which was proven to be genuine in a laboratory test. According to the paper, one of the dealers also offered two missiles with warheads. ${ }^{136}$ Fortunately, neither the Finnish newspaper's report nor other allegations of nuclear weapons thefts in Russia and other former Soviet republics have thus far proven to be true. Russian authorities have never confirmed any thefts of nuclear weapons, while IAEA classified these two and other allegations of nuclear theft in Russia as "not relevant."

\footnotetext{
133 Orlov Interview, April 2002.

134 “Interior Ministry Sees Organized Crime Merge With Terrorist Groups," Interfax, November 14, 2002.

135 “Russia Tightens Curbs to Stop Nuclear Arms Spread,” Reuters, December 30, 1992, available at NIS Nuclear Trafficking Database, Center for Nonproliferation Studies, Monterey Institute of International Studies, available at http://www.nti.org/db/nistraff/1992/19921270.htm as of July 4, 2002. Database on Nuclear Smuggling, Theft and Orphan Radiation Sources, Institute for International Studies, Stanford University, classified this case as least reliable on a three-point scale of reliability.

136 “Russian Dealers Selling Plutonium,” Finnish paper Itableti quoted by Reuters, July 14, 1993. Database on Nuclear Smuggling, Theft and Orphan Radiation Sources, Institute for International Studies, Stanford University, classified this case as least reliable on a three-point scale of reliability.
} 


\section{Conclusion}

There is no credible, publicly available evidence that either officers or civil personnel at Russian nuclear facilities have been swayed to attempt the theft of a nuclear bomb, and Russia is taking measures to ensure that nuclear arms theft will not occur in the future. Russian government agencies continuously strive to increase security at Russian nuclear facilities with the West's technical and financial assistance. These efforts decrease the opportunities that personnel and outsiders have to steal nuclear materials and weapons each year.

Russian armed forces and law-enforcement agencies are keeping radical separatists on the run in Chechnya and other parts of the North Caucasus, decreasing their capability to plan and execute acts of catastrophic nuclear terrorism. While Russia's military campaign has decreased the radical separatists' capabilities to stage acts of nuclear terrorism, however, it has also increased their motivation to commit such acts, as radical separatists remain unable to avoid marginalization inside Chechnya and other North Caucasian republics. It is worth recalling that when Dudayev feared that federal forces might crush Chechnya's independence bid, Khasukhanov designed the submarinehijacking plan in 1995.

Basayev, Maskhadov, and other leaders of Chechen separatists are now much more marginalized than Dudayev was in 1995. These leaders are becoming increasingly frustrated with their failure to win Chechnya back by means of conventional warfare, conventional terrorism, or peace talks. As their frustration increases, so does their motivation to attempt an act of nuclear terrorism. Until the botched hostage-taking raid of October 2002, separatist leaders still believed that a conventional terrorist act or a conventional military operation, like the surprise seizure of 
Grozny, could successfully push the Russian military out of Chechnya or cause a much-needed ceasefire. $^{137}$ Now, leaders of radical separatists may perceive nuclear terrorism as their only option.

The argument that these leaders have not exercised this option in the past because it is problematic to acquire components needed to assemble a dirty bomb is difficult to believe. As the cases highlighted in this paper demonstrate, they have possessed such components and it is relatively easy to assemble a dirty bomb.

It is also difficult to believe that Basayev has refrained from nuclear terrorism because he believes this would be morally offensive. After all, Basayev led the bloody Budyonnovsk raid in 1995, ordered the planting of radioactive materials in Moscow the same year, and has admitted involvement in the October 2002 Moscow theater hostage-taking raid.

These leaders may have been disheartened by the fact that the Russian leadership has refused to bow to radioactive blackmail in the past, as was the case when Basayev threatened to detonate a container with radioactive materials in 1995. Moreover, Basayev's failure to keep his word and detonate his crude radiological bomb may also indicate that this warlord and other leaders of radical separatists would invariably fail to back their WMD rhetoric with action, fearing an overwhelming and devastating response from Moscow. It is possible, however, that Basayev, Maskhadov, and others have refrained from attempts of nuclear terrorism because they doubt whether the explosion of a radiological bomb would cause sufficient casualties and destruction to intimidate Russia into withdrawing from Chechnya and the North Caucasus.

\footnotetext{
137 As recently as in June 2002 Maskhadov was planning to have separatists seize Grozny in a surprise attack, Russian Defense Minister Sergei Ivanov told reporters on June 26, 2002. On the same day Russian media reported that Maskhadov had written a letter to the Kremlin, offering to establish a ceasefire and hold peace talks. "Maskhadov Nachal Rabotu Nad Dzhikhadom-3" [Maskhadov has started to work on jihad-3], Gazeta.ru, 26 June 2002, available at http://www.gazeta.ru/2002/06/25/mashadovna4a.shtml as of June 26, 2002.
} 
But these doubts might disappear if the radical separatists acquire expertise to assemble a nuclear bomb that they believe, if detonated, would cause massive casualties and may lead to Russia's withdrawal if backed by credible evidence that they are capable of detonating another bomb. It could be only a matter of time before either Chechnya-based radical separatists or their allies in foreign terrorist networks acquire such expertise to place the last link in the deadly chain of nuclear terror and swing it violently toward Russian cities.

The risk of such a development is too lethal to ignore. Russian authorities need to design and implement a sustainable set of measures to prevent thefts of weapons-grade materials. These thefts have happened in the past and may happen again if Russian authorities do not act to ensure adequate security at all nuclear facilities and deny radical separatists the possibility to assemble and explode a nuclear bomb, even if they acquire the deadly expertise. 


\section{Appendix: Recommendations for Securing Nuclear Materials and Preventing Catastrophic Nuclear Terrorism}

Administrative Recommendations

1. Review what Russia requires at the local and federal levels in terms of detection, prevention, protection, containment, and attribution of terrorist attacks involving nuclear materials and arms, including acts of catastrophic terrorism; develop a plan of action on the basis of this review's findings, including the identification of financial, human, and technical resources needed to implement this plan. The plan should provide for the training of lawenforcement, security, health, and other public officials to deal with the identification of WMD/NBC catastrophic terrorist attack threats, interdiction, and consequence management. This plan should also include a comprehensive program of civil defense for the population. As part of this plan, it is necessary to design and implement the following programs:

a. A federal program to dispose of those redundant nuclear warhead and materials already produced, including the blend-down of HEU.

b. A federal program to identify redundant nuclear facilities, including research, production, storage, and disposal facilities and, if feasible, either phase them out or convert them with sufficient finances allocated for retirement packages and the retraining of personnel, including guards, to prevent brain drain as well as for ensuring that the phased out facilities will become neither an environmental danger nor a source for illegal acquisition of nuclear materials and technologies. This program should provide for the maximally reasonable concentration of nuclear materials at selected, best-guarded facilities. Funding for the remaining facilities 
should be boosted to further improve security, increase wages, and award grants to personnel to prevent brain drain.

c. R\&D for ensuring the adequate security of research, production, storage, disposal, and transportation of nuclear materials. Finance R\&D for early detection, interdiction, and containment of nuclear terrorist attacks.

d. Installation of checkpoints at all trans-border roads. Installation of nuclear detectors at these checkpoints as well as at all major transit centers.

Responsibility: Security Council, Ministry of Atomic Energy, nuclear security watchdog Gosatomnadzor, Ministry of Industries, Science and Technologies, flagships of atomic industry and defense industry, Federal Security Service, Foreign Intelligence Service, Ministry of Foreign Affairs, Interior Ministry, General Prosecutor's Office, Chief Military Prosecutor's Office, Federal Border Guard Service, State Customs Committee.

2. Empower Gosatomnadzor to oversee the review and implementation of the plan of actions. Gosatomnadzor should oversee security of all facilities that produce, store, use, transport, and dispose of nuclear materials, including military facilities. ${ }^{138}$ The agency should have its own separate budget, power of veto on other agencies' nuclear security expenditures, and a leader who would have a ministerial rank and direct access to the president.

Responsibility: President of the Russian Federation.

3. Organize a center within the newly-empowered Gosatomnadzor to accumulate all intelligence data on possible nuclear terrorism threats collected by Russia's law-enforcement and security community, analyze it, and manage its distribution and use by those agencies

${ }^{138}$ Gosatomnadzor presently lacks funds and has been stripped the right to inspect military nuclear facilities. 
responsible for nuclear security, counter-terrorism, law-enforcement, border security, and health. Build a joint database between the security agencies and law-enforcement agencies on criminals and suspected terrorists, using data distributed by this center as well as information from other government sources. Link this database not only to both lawenforcement, but also to transit centers.

Responsibility: Gosatomnadzor, Federal Security Service, Foreign Intelligence Service, Ministry of Foreign Affairs, Interior Ministry, General Prosecutor's Office, Chief Military Prosecutor's Office, Federal Border Guard Service, State Customs Committee, Defense Ministry, Ministry of Atomic Energy, Federal Agency for Government Communications and Information.

\section{Political Recommendations}

1. Negotiate with moderate factions of Chechen and other North Caucasian separatists to encourage them to lay down arms with firm guarantees of immunity, political representation and other carrots to undermine the positions of radical separatists. In choosing mediators for negotiations the Russian presidential administration should include former president of the Republic of Ingushetia Ruslan Aushev and high-ranked regional policy officials in the Russian presidential administration.

Responsibility: the envoy of the President of the Russian Federation in the Southern Federal District, the present Chechen administration.

\section{Legislative Recommendations}


1. Amend the Criminal Code to increase sentences and fines for illegal acquisition, transportation and purchase of nuclear materials. Also boost internal compliance in the nuclear sector by raising fines for negligence and removing those guilty of violations. Responsibility: Gosatomnadzor and the Prosecutor General's Office should cooperate to draft the amendments and the president of the Russian Federation should submit them for the parliament's consideration.

\section{International Recommendations}

1. Interact with G8 to ensure that the majority of the $\$ 20$ billion pledged at the June 2002 summit of Kananaskis for dismantling decommissioned nuclear submarines, disposing fissile materials, and employing former weapons scientists will be earmarked for Russia. Prepare a detailed plan for how this sum would be spent with transparency and openness for inspections ensured. The sum should be spent on both quick solutions and sustained efforts to ensure adequate security at all facilities involved in research, production, storage, disposal and transportation of nuclear materials.

Responsibility: Ministry of Foreign Affairs, Gosatomnadzor.

2. Propose a G8 structure that would deal specifically with issues of WMD/NBC security, terrorism and proliferation. This structure should ideally be allocated budget resources and enforcement capabilities.

Responsibility: President of the Russian Federation.

3. Engage Israeli, United States, Japanese and other anti-terrorist experts and government practitioners to assist in domestic preparedness. 
Responsibility: Gosatomnadzor, Federal Security Service, Foreign Intelligence Service, and Ministry of Foreign Affairs.

4. Maintain and increase intelligence sharing on nuclear terrorism with UNITED STATES, NATO, EU and other allies.

Responsibility: Foreign Intelligence Service. 


\title{
INTERNATIONAL SECURITY PROGRAM
}

The International Security Program addresses the most important challenges to U.S. national security and international security in the quarter-century ahead. As the first issue of the journal International Security stated in 1976, "We define international security broadly to include the full array of factors that have a direct bearing on the structure of the international sy stem and the sovereignty of its members, with particular emphasis on the use, threat, and control of force."

Program researchers analy ze security issues rigorously, draw prescriptive conclusions, and communicate their recommendations directly to makers of public policy and shapers of public opinion. The program also seeks to advance scholarship in security studies by contributing to significant academic debates through its own research activities and by publishing the leading journal in the field, International Security. Each year ISP develops and trains new talent in security studies by hosting a dozen pre-and postdoctoral research fellows. The program also presents its research in the book series, BCSLA Studies in International Security.

\section{INTERNATIONAL SECURITY}

The basic mission of Internation al Security is to publish articles on defense and foreign affairs that combine policy relevance with scholarly analysis and research. The journal seeks to bridge the gap between contemporary security policy issues and academic research on international security studies. We define the field of international security studies broadly, to include nonmilitary as well as military threats to the security of states. Compared to some other journals, we also interpret policy relevance broadly to include many articles that bear on general theoretical questions - such as the causes of alliances or the role of international institutions - as well as historical topics, ranging from the origins of the First World War to U.S. nuclear strategy in the 1950's. As the editors of the journal wrote in its first issue, our intended audience includes the "scholars, scientists, industrialists, military and government officials, and members of the public who bear a continuing concern" for the problems of international security.

\section{BCSIA STUDIES IN INTERNATIONAL SECURITY}

In 1991 ISP created a new book series, the BCSLA Studies in International Security, to provide an outlet for policy-oriented research and analy sis in the field of international security. The first volume published in the series, Soviet Nuclear Fission: Control of the Nuclear Arsenal in a Disintegrating Soviet Union, attracted considerable attention and contributed directly to the passage of the original legislation (known as the NunnLugar Act) authorizing the expenditure of U.S. funds to reduce the nuclear dangers in the former Soviet Union. Since that auspicious beginning, further titles have covered a diverse array of topics, including nuclear, biological and chemical weapons; other aspects of the nuclear dangers emanating from the former Soviet Union; the CFE treaty in Europe; Russian foreign and security policy; transatlantic relations; security in the Middle East; and the democratic peace. The BCSLAStudies in International Security series is published by The MIT Press.

\author{
International Security Program \\ Belfer Center for Science and International Affairs \\ Harvard University, Kennedy School of Government \\ 79 John F. Kennedy Street \\ Cambridge, Massachusetts 02138 \\ http://www.ksg.harvard.edu/bcsia \\ Program phone number 617-495-4708 Editorial office 617-495-1914 Facsimile 617-496-4403
}




\title{
ISP STAFF
}

Stephen M. Walt, Faculty Chair and Robert and Reneé Belfer Professor of International Affairs

Steven E. Miller, Program Director

Michael E. Brown, Co-Editor, International Security

Owen R. Coté, Jr., Co-Editor, International Security

Sean M. Lynn-Jones, Series Editor, BCSIA Studies in International Security

Diane J. McCree, Deputy Editor, International Security

Karen Motley, Executive Editor, BCSIA Studies in International Security

Michelle H. Von Euw, Editor, ISP Discussion Paper Series and Editorial Assistant, International Security

Gretchen Bartlett, Faculty Assistant to Ashton B. Carter

Kate Regnier, Faculty Assistant to Stephen M. Walt and Monica Duffy Toft

John Reppert, Executive Director, BCSIA

Gayle Schneider, Program Assistant

\section{ISP CORE FACULTY}

Graham T. Allison, Jr., Director, BCSIA; Douglas Dillon Professor of Government

Robert D. Blackwill, Belfer Lecturer in International Security (on leave); United States Ambassador to India

Ashton B. Carter, Ford Foundation Professor of Science and International Affairs

Paul Doty, Director Emeritus, BCSIA; Mallinckrodt Professor of Biochemistry, Emeritus

Richard Falkenrath, Assistant Professor of Public Policy (on leave); Special Assistant to the President and Senior Director for Policy and Plans, Office of Homeland Security

Shai Feldman, BCSIA, Member of the Board; Head, Jaffee Center for Strategic Studies, Tel Aviv University John P. Holdren, Teresa and John Heinz Professor of Environmental Policy

Brian Mandell, Lecturer in Public Policy

Ernest May, Charles Warren Professor of History

Matthew S. Meselson, Thomas Dudley Cabot Professor of the Natural Sciences, Department of Molecular and Cellular Biology; Director, Harvard Sussex Program on Chemical and Biological Weapons Limitation Joseph S. Nye, Jr., Dean, Kennedy School of Government; Don K. Price Professor of Public Policy Monica Duffy Toft, Assistant Professor of Public Policy; Assistant Director, John M. Olin Institute for Strategic Studies

\section{ISP FELLOWS}

\author{
Ivan Arreguin-Toft \\ Roberto Belloni \\ Marie Besancon \\ Stephen Brooks \\ Lucy Chester \\ Renske Doorenspleet \\ Thomas S. Foley \\ Kerry Fosher \\ John Garofano \\ Arman Grigorian \\ Peter Grose \\ Mark Haas \\ Kendall Hoyt \\ Bonnie D. Jenkins \\ Dmitry Kovchegin \\ Sarah Lischer \\ Gregory Mitrovich
}

\author{
Kevin Narizny \\ Sadako Ogata \\ Sean Patrick \\ Alisa R. Peled \\ Jeremy Pressman \\ David Rezvani \\ Richard Rosecrance \\ Benjamin Runkle \\ Margaret Sloane \\ Christopher P. Twomey \\ Bob van der Zwaan \\ Aaronette M. White
}




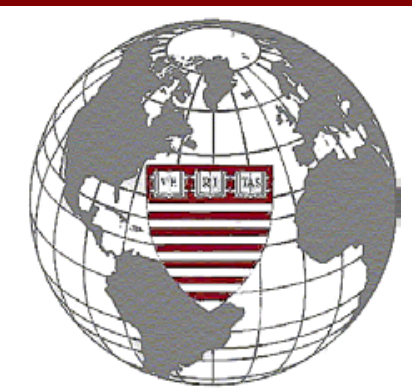

\title{
The Robert and Renée Belfer Center for Science and International Affairs
}

\author{
Graham T. Allison, Director \\ John F. Kennedy School of Government \\ Harvard University \\ 79 JFK Street, Cambridge, MA 02138 \\ Tel: (617) 495-1400; Fax: (617) 495-8963; Email: bcsia_ksg@harvard.edu \\ www.ksg.harvard.edu/bcsia
}

The Belfer Center for Science and International Affairs (BCSIA) is the hub of research, teaching, and training in international security affairs, environmental and resource issues, science and technology policy, and conflict studies at Harvard's John F. Kennedy School of Government. The Center's mission is to provide leadership in advancing policy-relevant knowledge about the most important challenges of international security and other critical issues where science, technology and international affairs intersect.

BCSIA's leadership begins with the recognition of science and technology as driving forces transforming international affairs. The Center integrates insights of social scientists, natural scientists, technologists, and practitioners with experience in government, diplomacy, the military, and business to address these challenges. The Center pursues its mission in five complementary research programs:

- The International Security Program (ISP) addresses the most pressing threats to U.S. national interests and international security, analyzing the forces shaping these problems and identifying opportunities for effective intervention into the policy process.

- The Science, Technology and Public Policy Program (STPP) analyzes ways in which public policies influence science and technology for security, sustainability, and economic competitiveness, how S\&T policies are made, and how S\&T influence and are influenced by society.

- The Environment and Natural Resources Program (ENRP) is the locus of Harvard's interdisciplinary research on resource and environmental problems and policy responses. ENRP has a three-pillared approach, with emphasis on teaching, research, and outreach.

- The Strengthening Democratic Institutions Project (SDI) catalyzes support for transformations in Russia, in the Caspian region, and the other countries of the former Soviet Union to sustainable democracies, free market economies, and cooperative international relations.

- The WPF Program on Intrastate Conflict, Conflict Prevention and Conflict Resolution analyzes the causes of ethnic, religious, and other conflicts, and seeks to identify practical ways to prevent and limit such conflicts.

The heart of the Center is its resident research community of more than 150 scholars including Harvard faculty, analysts, practitioners, and each year a new, interdisciplinary group of research fellows. BCSIA sponsors frequent seminars, workshops and conferences, maintains a substantial specialized library, and publishes books, monographs and discussion papers.

The Center is supported by an endowment established with funds from Robert and Renée Belfer, the Ford Foundation and Harvard University, by foundation grants, by individual gifts, and by occasional government contracts. 